واقع الذكاءات المتعددة وعلاقته بتميز الأداء لاى العاملين بالإششاد الزراعي في محافظة الوادي الجديد

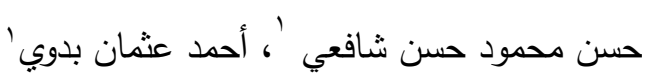

بإستخدام الحاسب الآلي لبرنامج الحزمة الإحصائية للعوم

الإجتماعية SPSS.

أهم النتائج البحثية: - ألماعة

1- اتضح أنه بتصنيف المبحوثين وفقًا لارجة تميز الأداء

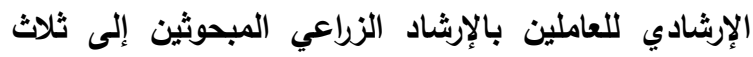

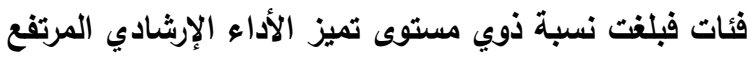

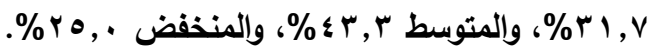

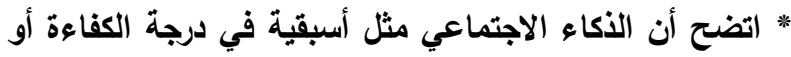
الأداء الظاهري لواقع الذكاءات المتعددة بالنسبة للعاملين بالإرشاد الزراعي المبحوثين بالوادي الجديد وانعكس ذلتك في التاني استجاباتهم على عبارات الجانب المعرفي والجانب السنوكي المتمثل في مهارات التعامل مع المزارعين. وأن الذكاء البيئي

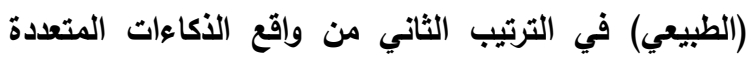

للمبحوثين، ثم يليه الأكاء الثخصي بصورة متوسطة. * بينما اتضح أن الذكاء المنطقي في ترتيب متأخر بالنسبة للأكاءات لاى العاملين بالإششاد الزراعي المبحوثين ، وكذلك فئك

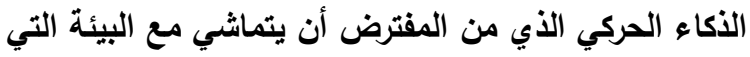
تحكم محافظة الوادي الجديد يلي ذلك الذكاء اللغوي الذي لأني يأتي في الترتيب قبل الأخير بالنسبة للأكاءات ثم يليه أخيرًا

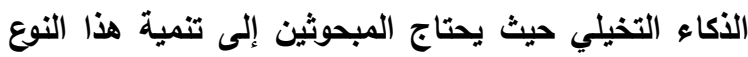

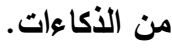
r- وجود علاقة إرتباطية طردية عند مستوى (1 +, •) بين درجة تميز الأداء الإرشادي للعاملين بالإرشاد الزراعي المبحوثين

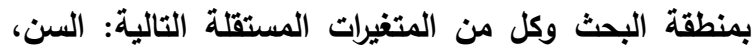

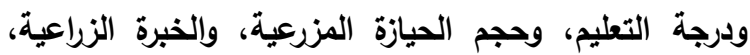

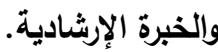

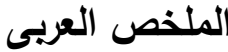

استهلف هذا البحث بصفة أساسية دراسة واقع الذكاءات المتعلدة وعلاقته بتميز الأداء لاى العاملين بالإرشاد الزراعي في محافظة الوادي الجليد من خلال تحقيق الأهداف الفرعية التالية: (1) التعرف على واقع تميز الأداء لاى العاملين بالإرشاد الزراعي

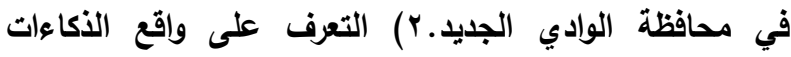
المتعددة لاى العاملين بالإرشاد الزراعي في محافظة الوادي العادي العادي

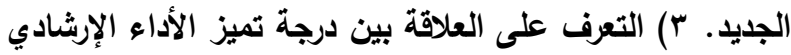

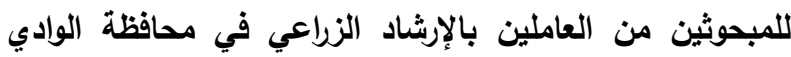

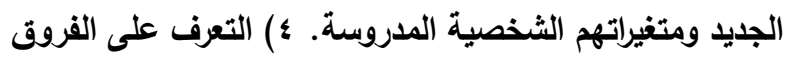
أو الاختلافات في ادراك العاملين بالإرشاد الززاعي في محافظة التراتية الوادي الجديد لواقع الأكاءات المتعددة والتي تُنزى لتميز الأداء والمتغيرات الثخصية للمبحوثين المدروسة. وتم إجراء البحث على القائمين بالعمل الارشادي بمحافظة الوادي الجديد موزعين

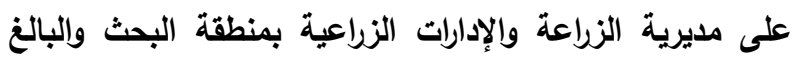

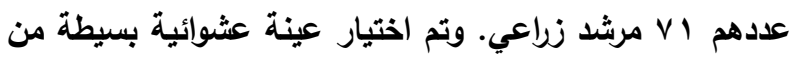
واقع كثوف المرثدين الزراعيين على مستوى محافظة الوادي

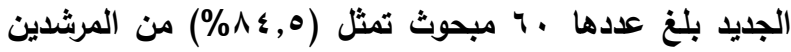
الزراعيين المبحوثين طبقا لمعادلة كريجسي ومورجان، تم توزيعهه

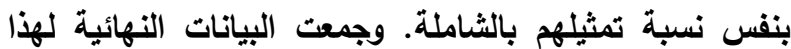
البحث عن طريق المقابلة الثخصية للمبحوثين بواسطة استمارة

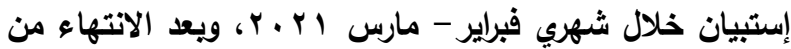

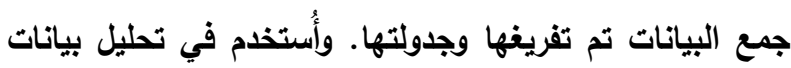

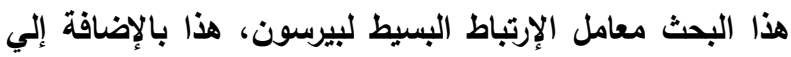
الحصر العددي والعرض الجدولي بالتكرار والتنسب المئوية، والمتوسط الحسابي، والإنحراف المعياري، والمتوسط الحسابي المرجح، لعرض بعض النتائج التي تم الحصول عليها، وذلك

معرف الوثيقة الرقي: 10.21608/asejaiqjsae.2021.210858 'قسم الإرشاد - شعبة الدراسات الاقتصادية والاجتماعية- مركز بحوث الصحراء

Corresponding author: Hassan.Shafey@yahoo.com

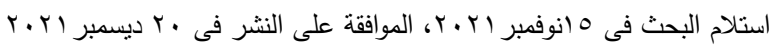


يتطلب التعرف على امكانياته العقلية، وبالتالي الإسهام في بناء الدولة العصرية. وتتضح أهمية الذكاءات المتعددة وما يرتبط بها من نتوع القدرات داخل الفرد من كونه عنصرًا ضروريًا لتحقيق أهداف المنظمة وأهداف العاملين فيها، ومن اسهامه في تتمية المنظمة من خلال العمل على تطوير الأبعاد المختلفة داخلها، ومن تاثير نوع الذكاءات المتعددة على نمو امكانيات العاملين في حل مشكلاتهم بأنفسهم بشكل مؤثر وفعال. وهو ما تتبه إليه الباحثون والخبراء في المنظمات والمؤسسات للمردودات الاقتصادية من زيادة وتطوير في الأداء الإحترافي

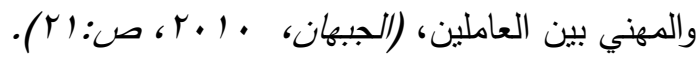
ويتميز الإنسان في سلوكه الظاهر والباطن بالتعقيدات والتغيرات، لأن لكل إنسان عقل يدرك ويفهم ويتعلم به، ويمنلك من القدرات العقلية المتعلقة بالقدرة على التحليل، والتخطيط وحل المشكلات، ورسم الاستتاجات، وسرعة المحاكاة العقلية، والقدرة على التفكير المجرد، وجمع الأفكار

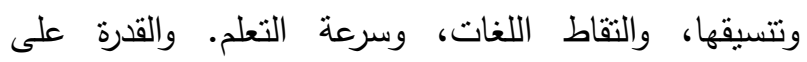
الإحساس وفهم مشاعر الآخرين، (المختار، وحامد، 7 ـ بـ، ص:V

واستشراف دور الذكاء في المستقبل يتطلب أن نفهم ليس فقط الدور الإيجابي له، بل وأن نفهم كذلك ما يضعه من حدود أمام أداء الإنسان، وتزداد دلالة الذكاء وقدرات التفكير في عصر المعلومات والاقتصاد القائم على المعرفة، وبالمنل فإن جوانب القصور في هذه القدرات تضع حدودًا لقدرة الإنسان على مواجهة تحديات هذا العصر أكثر من أي وقت مضى، وفي ضوء هذه الأهمية الثديد للذكاء تبرز الحاجة إلى استشراف الملامح الأساسية لمستقبل فهم الذكاء ودراسته

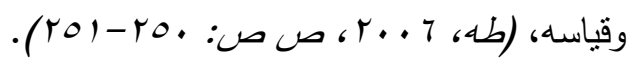

ومن منطلق أن الخدمة الإرشادية الزراعية هى المخرجات

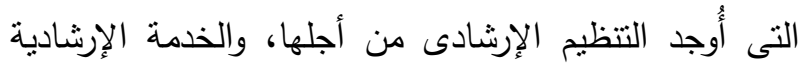

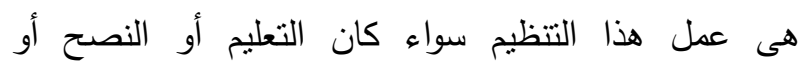

r- وجود علاقة إرتباطية طردية عند مستوى ( ( ., ·) بين درجة الكفاءة أو الأداء الظاهري لواقع الأكاءوات المتعددة للعاملين بالإرشاد الزراعي ويين المتغيرات المستقلة التالية: درجة

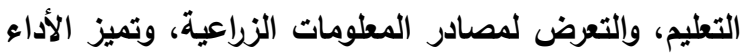
الإرشادي. الكلمات المفتاحية: الأكاءات المتعددة، تميز الأداء، الوادي الجديد.

\section{المقدمة والمشكلة البحثية}

يشكل بناء الإنسان واستثمار قدراته أهم تحديات القرن الحادي والعشرين بتغيراته التكنولوجية المتسارعة في مختلف التهن جوانب الحياة، فالعقل الإنساني هو أعظم النعم التي كرم الله

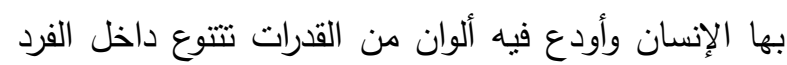
الواحد في تتسيق متكامل لتعزيز ما نعرفه بالذكاء، وتعدد وتتوع هذه القدرات الإنسانية يعنى أننا لسنا أمام ذكاء واحد ينتهي به الأمر بل أنماط متعددة من الذكاء يتعامل كل نمط لإلهاء مع لون خاص من الخبرات. وباختلاف هذه الخبرات يختلف الأفراد في قدراتهم ونظرتهم للعمل ودرجة ارتباطهم واستجابتهم ومستويات الجهود المبذولة، وهو ما بعرف بالذكاءات المتعددة، التي تُمكن الثخص من تمييز جوانب السلوك لدى الأفراد مشاعرهم ومعارفهم واتجاهاتهم والتعامل معهم، مما يسهل من إمكانية التتبؤ بالسلوك، حتى يصبح من السهل أن تُعطي الناس ما يريدون إذا كنت تدرك ما هو وتعرفه دون نزاعات وخلافات، (الشوا، 10 • r، ص: ص: 10). والذكاء هو الأساس لكل مظهر من مظاهر النشاط العقلي، ولكل أداء إنساني، مما يؤكد أهمية دراسته وتحليل مكوناته، كما أن له أهمية بالغة في مختلف مجالات الحياة، في مجال التعليم والتدريب، بل وله الأهمية كذلك وأيضًا في المواقف الاجتماعية والحياتية على اختلافها وتتوعها، مما يؤدي إلى وضع الرجل المناسب في المكان المناسب، وهذا 
الأهداف الثاملة أو العامة أو التنفيذية أو التعليمية،

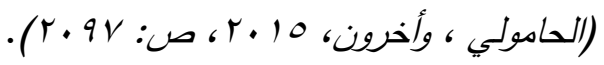
ومن هنا تتمثل مشكلة البحث في التعرف على واقع الذكاءات المتعددة لدى العاملين بالإششاد الزراعي في في محافظة الوادي الجديد للوقوف على مدى توفر هذه الذكاءات

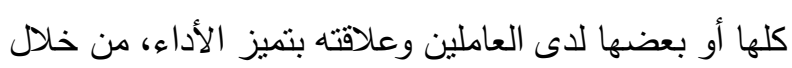
الإجابة عن التساؤلات البحثية النالية: ا ـ ما واقع تميز الأداء لدى العاملين بالإرشاد الزراعي في محافظة الوادي الجديد؟ r- ما واقع الذكاءات المتعددة (الذكاء الاجتماعي، والذكاء اللغوي، والذكاء الحركي، والذكاء المنطقي/ الرياضي،

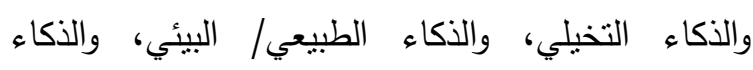
الثخصي/ الذاتي)، لدى العاملين بالإرشاد الزراعي

\section{بمنطقة البحث؟}

r- هل توجد فروق واختلافات في واقع تميز الأداء لدى العاملين بالإرشاد الزراعي في محافظة الوادي الجديد

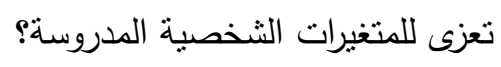

ع- هل توجد فروق واختلافات في ادراك العاملين بالإرشاد الزراعي في محافظة الوادي الجديد لواقع الذكاءات

المتعددة وعلاقتها بالمتغيرات الثخصية المدروسة؟

\section{الأهداف البحثية}

يستهدف هذا البحث بصفة أساسية دراسة واقع الذكاءات

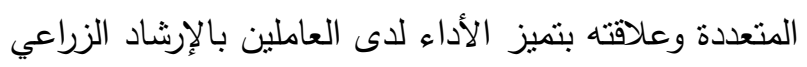
في محافظة الوادي الجديد من خلال تحقيق الأهداف الفرعية التالية: - 20 - n

1-التعرف على واقع تميز الأداء لدى العاملين بالإرشاد

$$
\text { الزراعي بمنطقة البحث. }
$$

r-التعرف على واقع الذكاءات المتعددة لدى العاملين بالإرشاد الزراعي بمنطقة البحث.
الاستشارة فهى الميدان الحقيقى لتحدى البقاء الإحترافى والمهنى للجهاز الإرشادى فى عالم يغمه العلم والتكنولوجيا

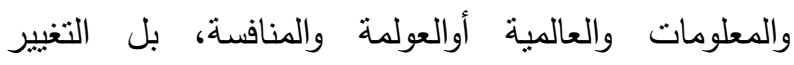
المستمر، فالعمل الإرشادى نفسه تغيير تعليمى من أجل جودة حياه المزارع وأسرته ومجتمعه المحلى، (فربي

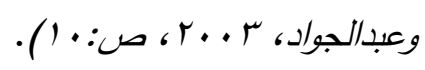
ويُعبر أداء الأفراد العاملين في الإرشاد الزراعي عن قدرة المنظمة الإرشادية في الوصول إلى أهدافها، واستغلال القدرات التظيمية التي تمكنها من تعظيم الموارد المتاحة لها بطرق كفوءة وفاعلة، فالأداء الماضي للعاملين بالإششاد الزراعي يمكن أن يؤثز على الأداء المستقبلي، والذي يعد من أكثر العوامل التي تسبب النتائج المستقبلية لكونه يمنل النواتج المتحققة من مجمل تفاعل نشاطات المنظمة الإرشادية لمواردها والتي من خلالها يمكن الحصول على أثخاص الإنئل جيدين مع الاحتفاظ بنتائج جيدة، كما أنه المؤشر الرئيسي في استخدام الموارد البشرية والمادية والمعلومانية المتاحة بالثكل الذي يحقق أعلى النتائج، فضلا عن إثباع حاجات

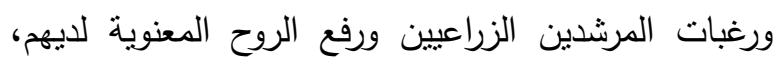

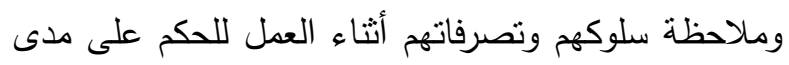
نجاحهم ومستوى كفاءتهم للقيام بالمهام الموكلة لهم، وهو بذلك يمثل النتيجة النهائية لعملهم، وعليه منل المرشد الزراعي الدعامة الرئيسية لنجاح العمل الإرشادي في المنظمة

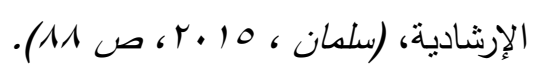

ويواجه الإرشاد الزراعي العديد في الآونة الأخيرة العديد من

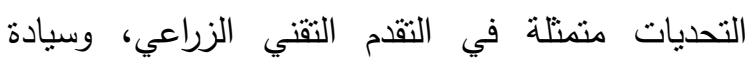
العولمة، وتوفير معايير الجودة في الخدمة الإرشادية،

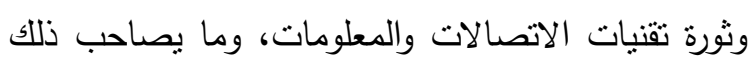
من تغييرات اقتصادية وسياسية واجتماعية وثثافية وديموجرافية عميقة، من أجل استيعاب كل تلاك المتغيرات وتوظيفها بما يحقق أهداف الإششاد الزراعي سواء 
وصف الذكاء على أنه كمية ثابتة يمكن قياسها، وأنها غير

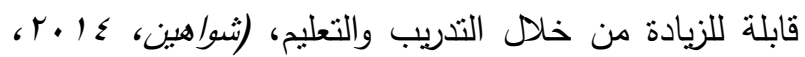

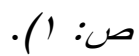

وأن المعنى اللُغوي اللاتنيني للأكاء يفيد بأنه: أنخاذ القرار،

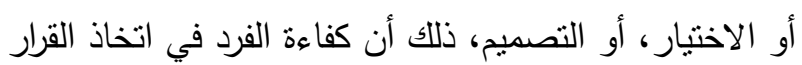

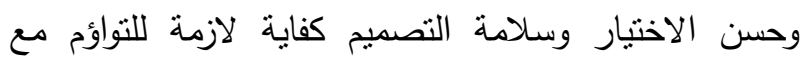

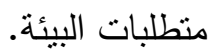

ومن ثم يمكن القول : ما الذي حدث من تغيرات أساسية

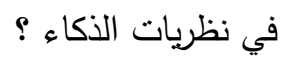

1- أن الذكاء ليس قدرة كلية، بل هو مركب من عمليات منعددة

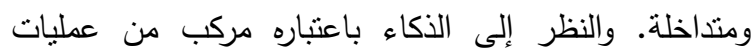
متعددة يمكن ملاحظتها وقياسها، ومن ثم تنخيص الفنشل بضعف بعض العمليات اللازمة للنجاح لاى هذا الفرد فيترتب

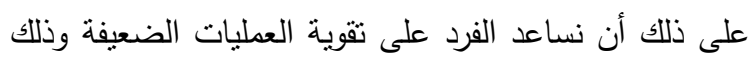
من خلال احاطته ببيئة ثرية تنتط الوظائف الخاملة، أو في ضوء تشخيص أوجه القصور لدى الفزد إن نوجهه بعيدًا عن النقال

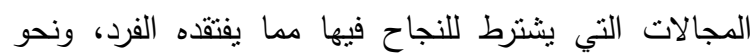
المجالات التي يستطيع النجاح فيها. وفي جميع الاحوال فإننا

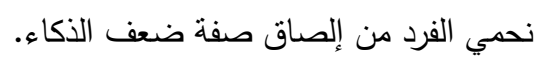

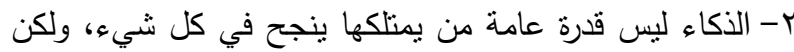

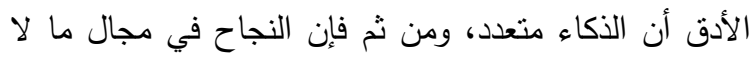

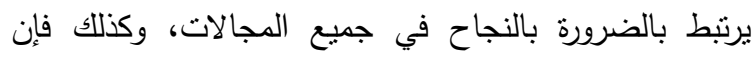

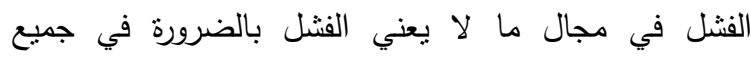

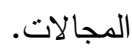

r- تغيرات القيمة النسبية في معادلة الوراثة والبيئة في نظريات الذكاءات الحديثة الأكثر فاعلية وتأثئرًا. ع- النظر إلى الذكاء باعتباره قدرًا ثابتًا، وليس باعتبان النباره طاقة قابلة

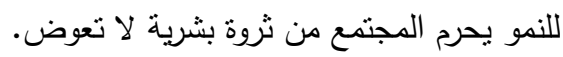

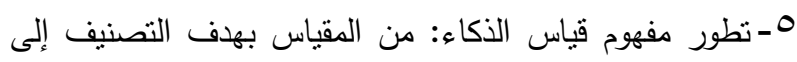
مستويات يتحدد مسنقبلهم على اسسها إلى نتخيص جوانب التباء القوة والضعف بلا داع إلى التمية أو الإثراء. ويضيف غاردنر (\$99 1) أن الذكاء المقاس بالطريقة التقليدية يحدد مجالًا معينًا أو تتظيمًا محددًا، أما منظور r-التعرف على العلاقة بين درجة تميز الأداء الإرشادي للمبحوثين من العاملين بالإرشاد الزراعي بمنطقة البحث ومتغيراتهم المستقلة المدروسة.

ع-التعرف على الفروق أو الاختلافات في ادرالك العاملين بالإرشاد الزراعي بمنطقة البحث لواقع الذكاءات المتعددة

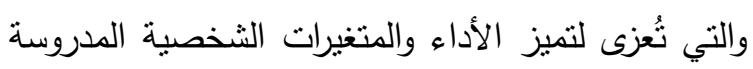
للمبحوثنين.

الإطار النظري: يمكن عرض الاطار النظري لهذا البحث

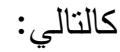

نظرية الذكاءات المتعددة: Theory of Multiple Intelligence واضع هذه النظرية هو العالم الأمريكي هوارد جاردنر Howard Gardner

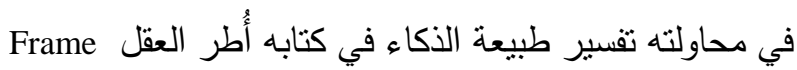
عام 1919 of Mind ملاحظاته للأفراد الذين يتمتعون بقدرات خارقة في بعض القات

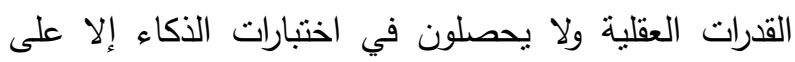
درجات متوسطة أو دونها مما قد يجعلهم يصنفون في مجال المعاقين عقليًا. ولقد أصبح مفهوم الذكاء من المفردات الني دماتي دخلت الحوارات اليومية، وتجاوزت بذللك حدود الدفاهيم

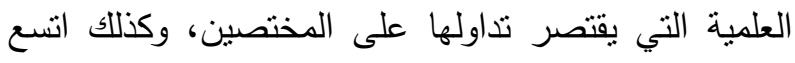
مفهوم الذكاء ليتجاوز وصف الإنسان إلى وصف المؤسسات

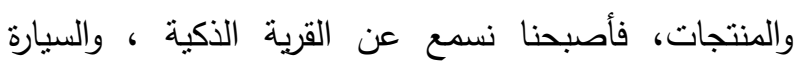

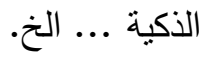

ولقد استخدم جاردنر معيارين في تعريفه للذكاء هما:

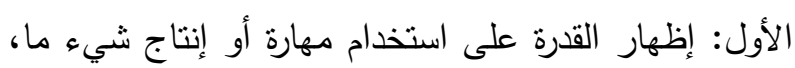

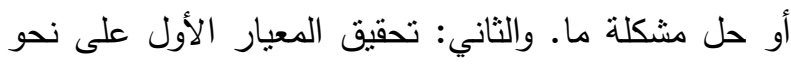
يحظى بتقدير النقافة التي يعيش هذا الثخص فيها، (جنسن،

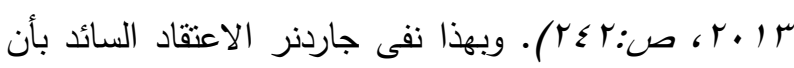
الذكاء عبارة عن قيمة محددة تستمر مع الإنسان مدى الحياة، وأن الإنسان يمثلاك قدرات ذكائية تبقى ثابتة ولا يمكن تغييرها

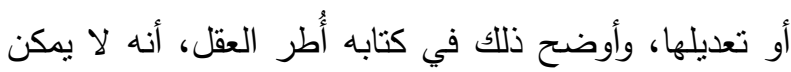


والوظيفة الاستكثافية وأحيانًا تسمى الاستفهامية، وهي أن اللغة أداة لاكتساب المعرفة والخبرات وطرح الأسئلة حول الموضوعات المتعددة، والوظيفة التخيلية، كاستخدام اللغة كأداة للهروب من الواقع من خلال كتابة الثعر والقصص للتنفيس عن الانفعالات، وأخيرًا الوظيفة الإخبارية الإعلامية،

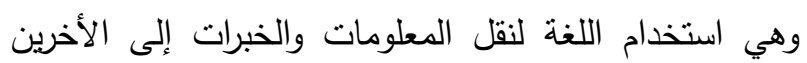
بهدف التأثير في سلوكهم.

r- الذكاء المنطقي الرياضي Logical -Mathematical: Intelligence يعني القدرة على استخدام الأرقام بكفاءة والقدرة على القئ التفكير المنطقي، ويتضمن الحساسية للنماذج والعلاقات

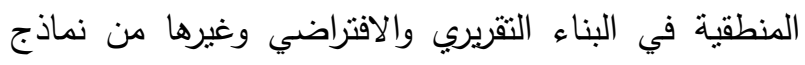
التفكير المجرد. وتتثتل نوعية العمليات المستخدمة في هذا الذكاء على التجميع في فئات والتصنيف والاستنلال والتعميم

$$
\text { واختبار الفروض والمدركات الحسابية. }
$$

ب- الذكاء الجسمي - الحركي Bodily - Kinesthetic Intelligence هو الخبرة في استخدام الفرد لجسمه للتعبير عن الافكار

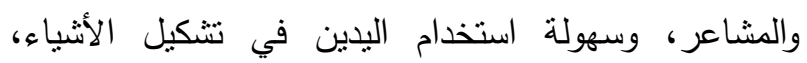
ويتضمن هذا الذكاء مهارات جسمية معينة مثل: التآزر، والنوازن، والمهارة، والقوة، والمرونة، والسرعة. ع - الذكاء الثخصي: Intra personal Intelligence وهو معرفة الذات والقدرة على التصرف المتوائم مع هذه المعرفة، ويتضمن أن يكون لديك صورة دقيقة عن نفسك

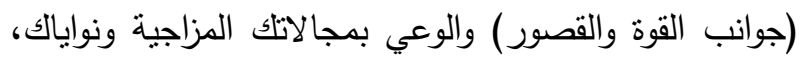
ورغباتكا، وقدرتك على الضبط والفهم والاحترام الذاتي. ويشار

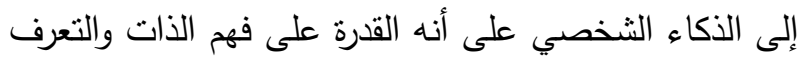
على كينونتها من خلال فهم الثخص لكشاعره وأحلامه، وتتظيم علاقته مع الآخرين، والتعرف على مكامن القوة والضعف لديه في اتخاذ القرار المعتمد على حاجاته ومشاعره

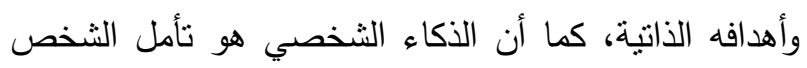
لذاته وفهمه لها وحب العمل بمفرده والقدرة على فهمه أهدافه
الذكاءات المتعددة فينظر لللكاء باعتباره قدرة سيكولوجية بيولوجية، يمكن الحصول عليها إلى مدى أكبر أو أقل نتيجة

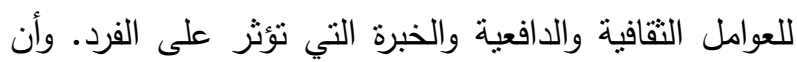

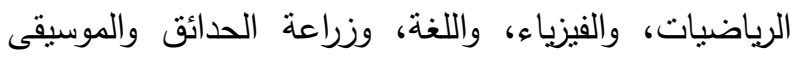
مجالات تتخلل الثقافة، ويمكن تحقيق أي مجال من خلال استخدام العديد من الذكاءات فعلى سبيل المثال فأن مجال الأداء في الفيزياء يتضمن الذكاء الرياضي (المنطقي) والثخصي، والجسمي الحركي. ويمكن وصف أنواع الذكاءات كما ذكرت في عدة كتابات

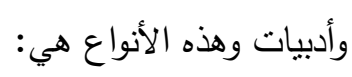

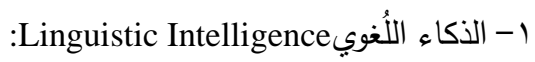
بأنه " القدرة على امتلاك اللغة والتنكن من استخدامها" وهو من أكثر الكفاءات الإنسانية التي تعرضت التئل للبحث. والثواهد التي تدعم هذا النوع من الذكاء مستقاة من علم نفس النس النمو، ويطلق عليه الذكاء اللفظي ويضم قدرات استخدام الدفردات اللغوية والقيام بالتحليل اللفظي وفهم المادة اللفظية ولفية وفهم المجاز والاستعارة. فالذكاء اللُغوي هو القدرة على توليد

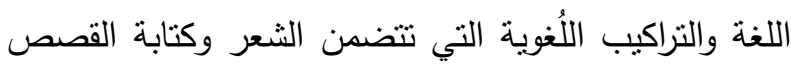
واستعمال المجاز والثغف بالكلمات والثغف باكتساب اللغات

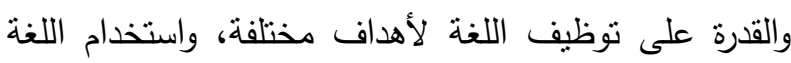

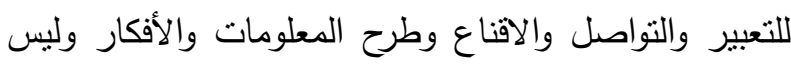
فقط إنتاج اللغة، ولكن حساسية عالية للفروق الطفيفة بين

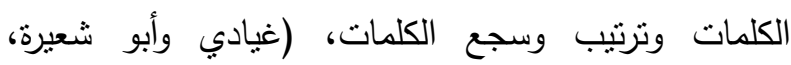

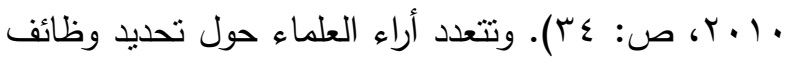

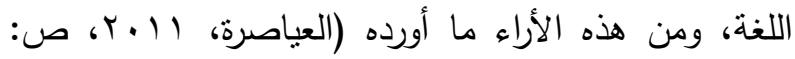

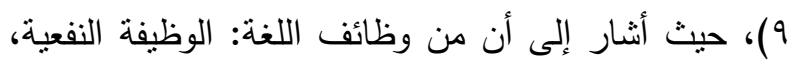
وهي استخدام اللغة في التعبير عن الحاجات، والوظيفة التنظيمية، وهي استخدام اللغة للسيطرة والتحكم في سلوك فلئن

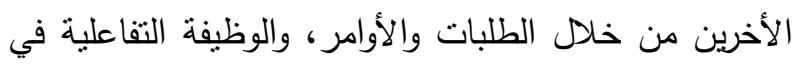

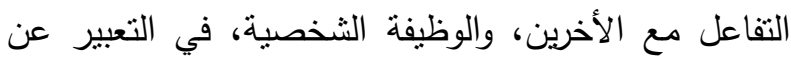
المشاعر والاتجاهات والأراء نحو الموضوعات المختلفة، 
والمعرفة الاجتماعية. والجانب السلوكي ويعني مدى فاعلية الفرد وتأثنراته الثخصية حال التفاعل مع الآخرين، (حسين،

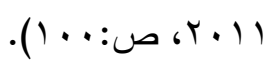

ج- الأكاء الموسيقي Musical Intelligence

ويعني القدرة على إدراك الموسيقي والتحليل الموسيقي والانتاج الموسيقي والتعبير الموسيقي، وبتضمن هذا الذكاء الحساسية للإيقاع، والنغمة، والميزان الموسيقي لقطعة ولتينة موسيقية ماء، كما يعني هذا الذكاء الحدسي الكلي للموسيقى أو الفهم التحليلي لها أو الربط بينها. : Spatial Intelligencee الذكاء المكاني - V القدرة على إدرالك العالم البصري - المكاني المحيط بدقة وفهم واستيعاب أشكال البعد الثالث وابتكار وتكوين الصور الذهنية والتعامل معها بغرض حل الماب المشكلات أو إجراء التعديلات وإعادة إنشاء التصورات الأولية في غياب المحفزات الطبيعية ذات العلاقة، وهذا الذكاء يتطلب الحساسية للون والخط والثكل والطبيعة والمساحة والعلاقات التي توجد بين هذه العناصر وكذلك القدرة على التصوير البصري.

1 : Naturalist Intelligence الذكاء الطبيعي يتجلى في القدرة على تحديد وتصنيف الاثياء الطبيعية

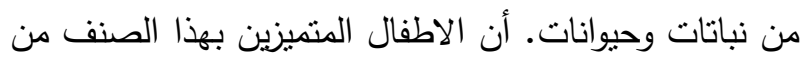
الذكاء تغريهم الكائنات الحية، ويحبون معرفة الثيء الكثير عنها، كما يحبون الوجود في الطبيعة وملاحظة مختلف

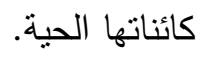

أن هذه الذكاءات موجودة لدى كل فرد ولكنها موجودة بتفاوت فقد يكون شخصًا ما لغويًا بدرجة عالية في حين يكون منطقيًا بدرجة أقل ولذلك لا نتعامل مع الآخرين على أنهم أذكياء أوقليلي الذكاء فكل شخص يمتلك درجات متفاوتة من كل نمط. وهكذا يكون لكل شخص بروفيل ذكاء وليس نسبة ذكاء.

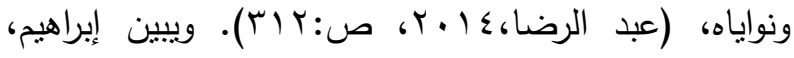

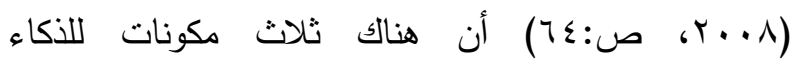
الثخصي، هي: 1- الوعي بالذات: ويظهر في كل نشاط

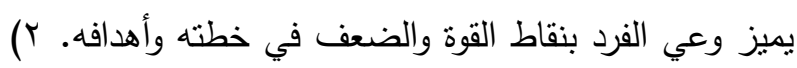
التأمل: ويظهر في كل نشاط يميز وعي الفرد لتخيلاته وحدسه أو نتبؤه. r) الاستقلالية: ويظهر في كل نشاط معرفي يتميز بالاعتماد الذاتي على التفكير · ويتسم الأشخاص الذين لديهم الذكاء الذاتي (الثخصي)، بالسمات بلاتيزي

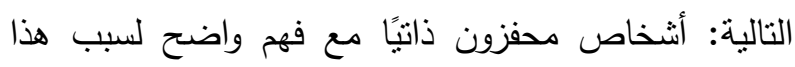
التحفيز، أشخاص يحبون أن يكونوا لوحدهم على أن يكونوا

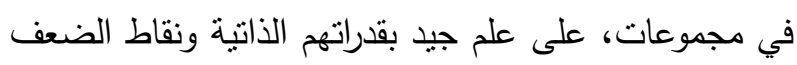
المحددة بالتفكير النقدي والتحليل، القدرة على تحليل الأفكار وتفكيك النظريات لفهم أساسهم، يفكرون في معظم الأحيان بعمق ويتسمون بالغموض، يحتفظون بسجل لأفكارهم ومشاعرهم وعواطفهم ويومياتهم، لديهم قدرات كبيرة على بلى بهمون صنع القرارات، وغير منأثرة بقوى خارجية، بالإضافة لقدرات

$$
\text { عالية على وضع الأهداف، وتحقيقها. }
$$

0 الذكاء الاجنماعي Inter personal Intelligence :

القدرة على إدراك الحالات المزاجية للآخرين والتمبيز بينها وإدراك نواياهم، ودوافعهم ومشاعرهم. ويتضمن ذلك الحساسية لتعبيرات الوجه والصوت والإيماءات، وكذلك القدرة على وده وملى التمييز بين المؤثرات المختلفة التي تعتبر هاديات للعلاقات الاجتماعية، كما يتضمن هذا الذكاء القدرة على الاستجابة المناسبة لهذه الهاديات الاجتماعية بصورة عملية بحيث تؤثر

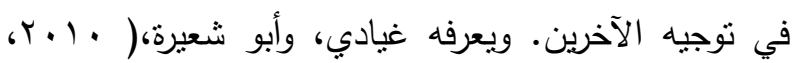

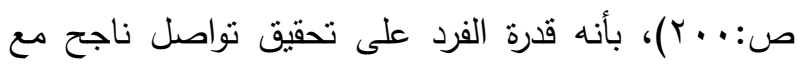
العالم الخارجي، وعالمه الداخلي على أن لا يدع فرصة تمر بـ لهر دون أن يستثرها في عملية التواصل. وأن مفهوم الذكاء الاجتماعي يتكون من جانبين هما: الجانب المعرفي: ويعني قدرة الفرد على فهم أو حل رموز السلوك اللفظي وغير هني اللفظي للآخربن، وتتمنل هذه القدرة في الإدراك والاستبصار ، 
يتبع رئيس قسم الارشاد الزراعي بالإدارة سبعة مسئولين بالادارة هم: مسئول المجالس الزراعية، ومسئول التنمية

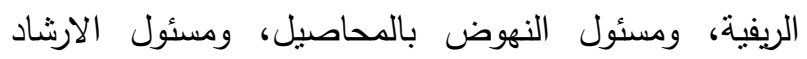

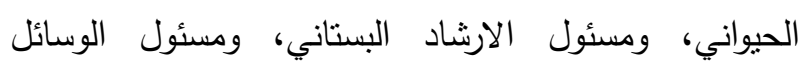
والبرامج، ومسئول المركز الارشادي.

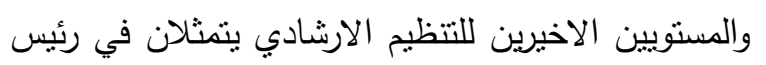
الوحدة الزراعية على مستوى القرية الذي يتبعه المرشدون

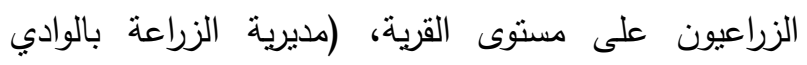

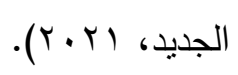

ويلاحظ من العرض السابق أن الهيكل التنظيمي

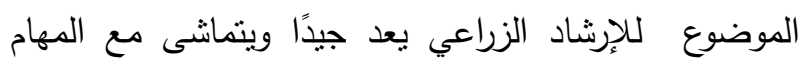

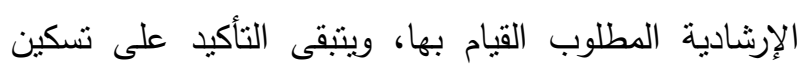

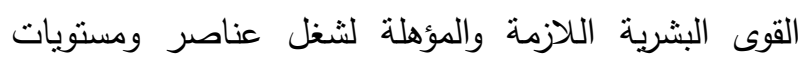

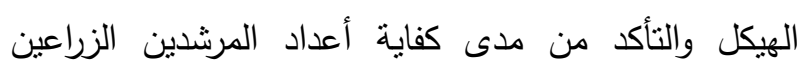
لتغطية النطاق الجغرافي للإرشاد الزراعي على مستوى القرى.

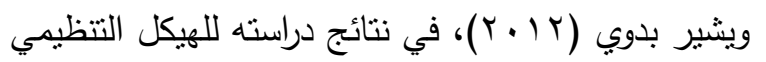

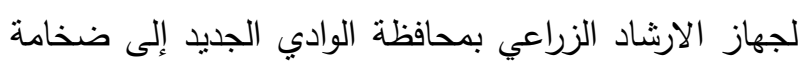

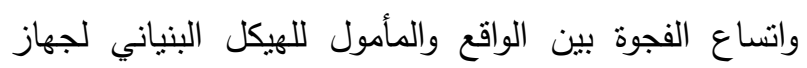

$$
\text { الإرشاد الزراعي حيث تبين الآتي: }
$$

القصور في التغطية الإرشادية لبعض المناطق حيث لم

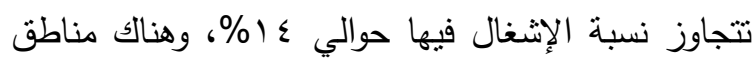

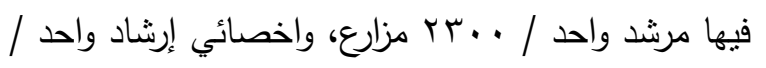

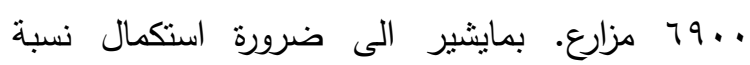

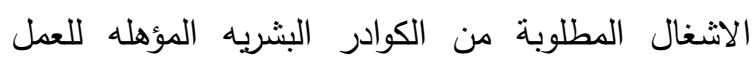

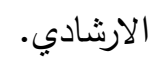
القصور في التغطية الجغرافية حيث أن هذه المساحات

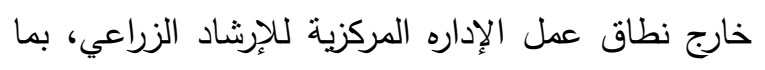
يشير الى ضرورة اعادة التتسيق مع كافة القطاعات.

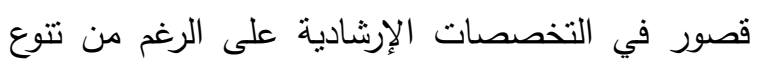
التركيب المحصولي النباتي وكذللك الإنتاج الحيواني بما لإنيا
تم إجراء هذا البحث في محافظة الوادي الجليد، وتبلغ مساحة

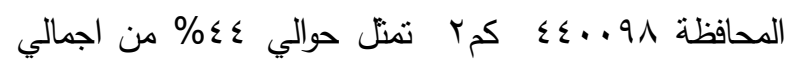

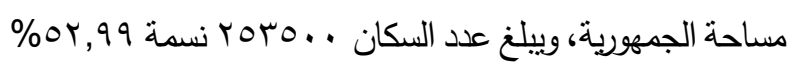

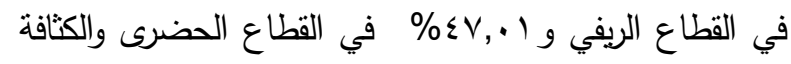

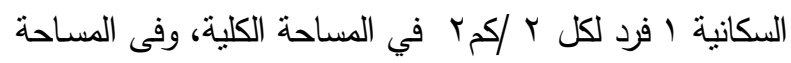
المأهولة ؟11 نسمة لكل اكمب ويمنل قطاع الزراعة الركيزة

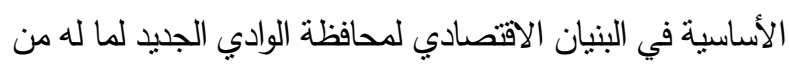

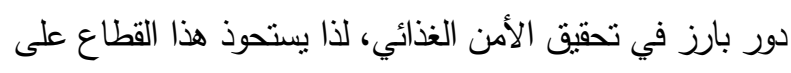

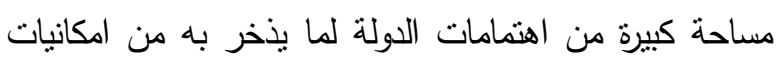

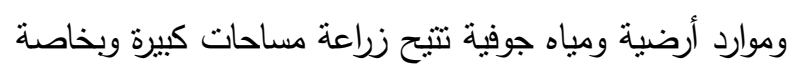
في مناطق التتمية الجديدة في درب الأربعين وشرق العوينات

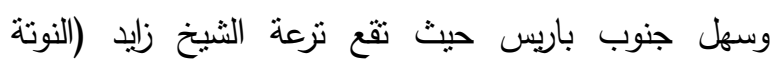

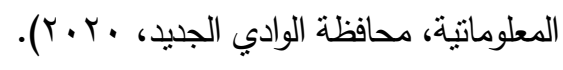
المجال البشرى: العاملين بالارشاد الزراعي بمحافظة الوادي واقع الارشاد الزراعي في محافظة الوادي الجديد: يمكن

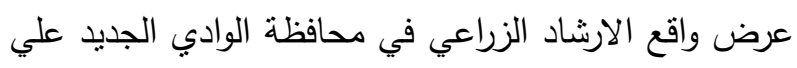
النحو النالي: - الني

الهيكل التنظيمي للارشاد الزراعي:

عناصر ومستويات الهيكل التنظيمي لجهاز الارشاد الزراعي بمحافظة الوادي الجديد:

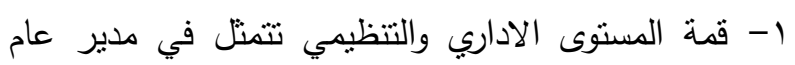
الزراعة يليه مدير عام الثئون الزراعية.

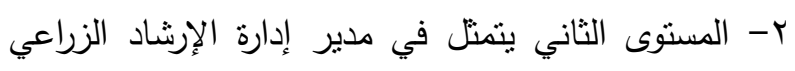

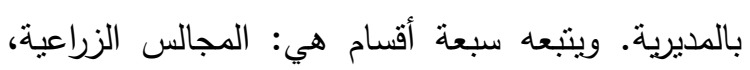

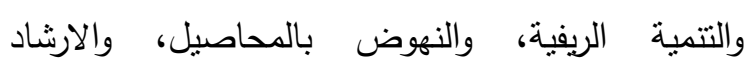
الحيواني، والارشاد البستاني، والوسائل والبرامج، والمراكز الارشادية. - الإني،

ץ- على مستوى الادارات الزراعية بالمركز يتبع مدير الادارة

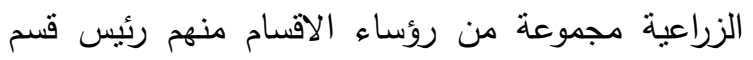
الارشاد الزراعي على مستوى الادارة. 


\section{أولاً:المتغيرات المستقلة:}

1- السن: يقصد به سن المبحوث حتى أقرب سنة ميلادية وقت إجراء البحث وتم قياس هذا المتغير من خلال الرقم

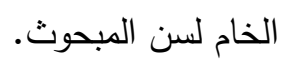

rأ- درجة التعليم: يقصد به حالة المبحوث التعليمية وقت إجراء البحث، من حيث كونه حاصل على دبلوم زراعة (درجة)، بكالوريوس زراعة (درجتان)، ماجستير فأعلي (باهن

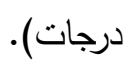

rاب- التخصص الدراسي: ويقصد به التخصص الزراعي

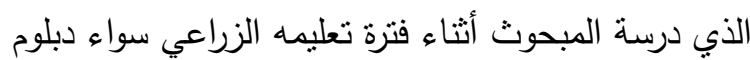

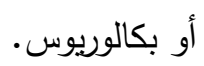

بأ- الوظيفة: يقصد به المسمى الوظيفي الذب يثغله

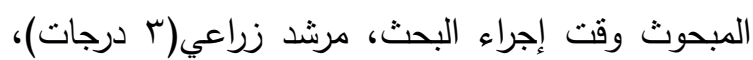
مشرف زراعي (درجتان)، رئيس وحدة زراعية (درجة واحدة).

rب- العمل الإضافي: يقصد به ما يقوم به الموظف من

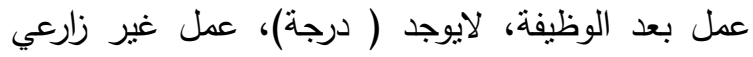

$$
\text { (درجتان)، عمل زراعي (ץ درجات). }
$$

ع - حجم الحيازة المزرعية: مساحة الاراضي الزراعية التي

$$
\text { يحوزها المبحوث. }
$$

ه- عدد أفراد الأسرة: يقصد به عدد أفراد أسرة المبحوث

$$
\text { المقيمين معه في وحدة معيشة واحدة. }
$$

צ- الخبرة الزراعية: عدد السنوات الني قضاها المبحوث في وهيد

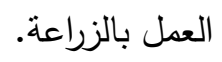

- V الخبرة الإرشادية: عدد السنوات التي قضاها المبحوث

$$
\text { في العمل بالإرشاد الزراعي. }
$$

1-عضوية المنظمات الرسمية: ويقصد بها عضوية المبحوث في المنظمات الاجتماعية والاقتصادية والسياسية القائمة بمنطقة البحث، وطبيعة الدور الذي يقوم به، حيث نم السؤال عن عضوية المبحوثين في خمسة
يشير إلي الحاجة إلي التتوع في التخصصات الإرشادية والتأهيل العلمي للكادر البشري مع التنريب المستمر. الإتساع الجغرافي والتباعد المكاني بما يشير إلي ضرورة توفير وسائل للإنتقال لتسهييل تقديم الخذمة الإشادية.

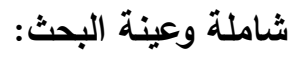

تم إجراء البحث على العاملين بالارشاد الزراعي بمحافظة الوادي الجديد موزعين على مديرية الزراعة والإدارات الزراعية بالوادي الجديد وهي: مديرية الزراعة بالخارجة (9 (19 مرشد

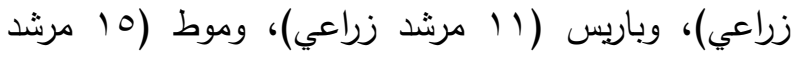

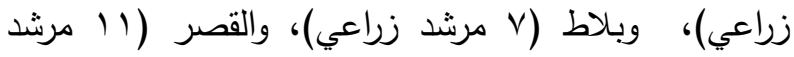
زراعي)، والفرافرة (^ مرشد زراعي) بإجمالي (اعل مرشد

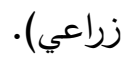
وتم اختيار عينة عشوائية بسيطة من واقع كثوف العاملين بالارشاد الزراعي على مستوى محافظة الوادي

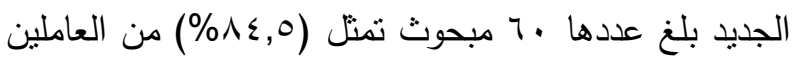

بالارشاد الزراعي المبحوثين طبقا لمعادلة: Krejcie\&) تم توزيعهم بنفس نسب تمثيلهم Morgan,1970,pp 607-610). بالثاملة على الإدارات الزراعية (الخارجة، وباريس، وموط،

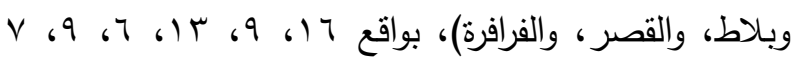

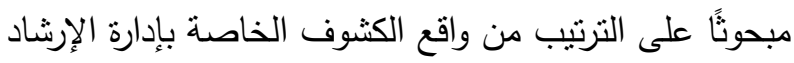
الزراعي مديرية الزراعة بالوادي الجديد، ( محافظة الوادي الجديد، مديرية الزراعة، (Y. (Y). إعداد أداة جمع البيانات تم إعداد إستمارة إستبيان كأداة لجمع البيانات البحثية من

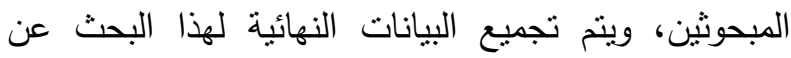
طريق المقابلة الثخصية للمبحوثين بواسطة إستمارة الإستبيان والتي تضمنت ثلاثة اجزاء علي النحو النالي:

أولا:الخصائص الثخصية المدروسه للعاملين بالارشاد

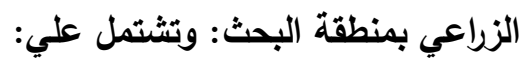
التعريفات الاجرائية والمعالجة الكمية لمتغيرات البحث:

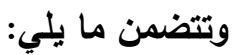


1 - محور التواصل مع المزارعين: يقصد به مدى تواصل

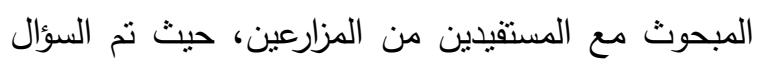

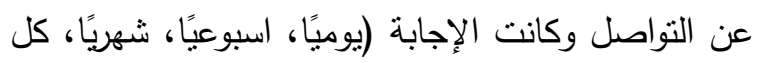

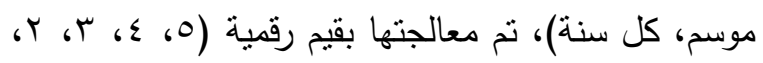

ץ- محور فعالية المشاركة في أنثطة الإششاد الزراعي: يقصد به حضور المبحوث لعدد من الفعاليات الإرشادية التي تم تتفيذها خلال العام الماضي، وتم قياسه من خلال (ع فعاليات)، متتوعة حيث طبيعة تلك المشاركة (الإعداد

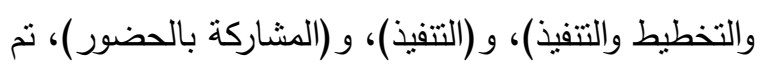

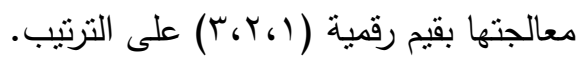
r- محور إدراك المشكلات الزراعية التي يمكن للإرشاد

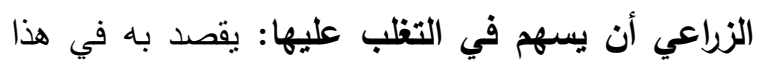

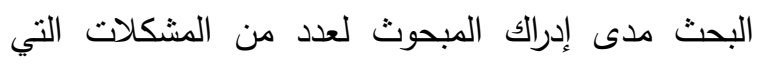

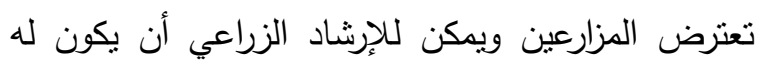

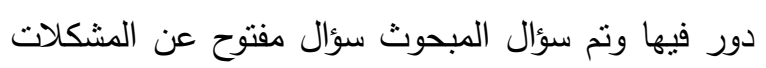

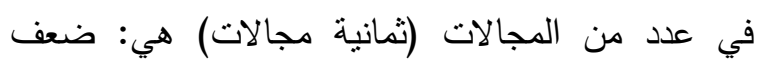
الكفاءة الإنتاجية للحاصلات الزراعية، مشكلات الثروة

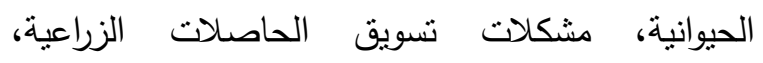
ومشكلات صيانة الموارد البيئية، ومشاكل إدارة الأعمال

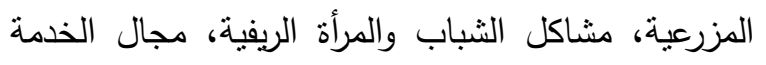
وتتمية وتتظيم المجتمع الريفي، ومجال تتمية القيادة

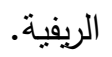

؛- محور الرضا عن الخدمات التي يقدمها الإرشاد الزراعي: استجابة المبحوث نحو عدد من العبارات التي لإني تصف الدور الذي يقوم به الإرشاد الزراعي في مواجهة

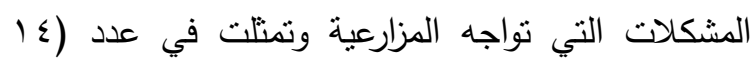

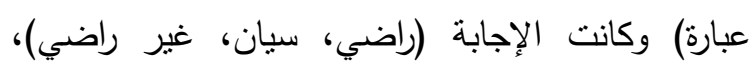

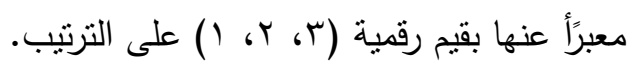

منظمات رسمية وكانت الاستجابات (غير عضو، عضو

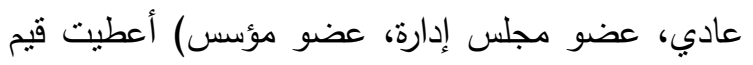

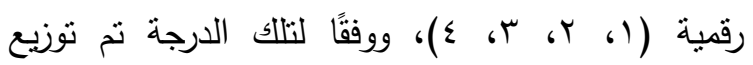
المبحوثين على ثلاث فئات للمشاركة هي: منذفضة، ومتوسطة، ومرتفعة.

9- التعرض لمصادر المعلومات الزراعية: يقصد به مدى ومن تعرض المبحوث لمصادر المعلومات التي يستقي منها

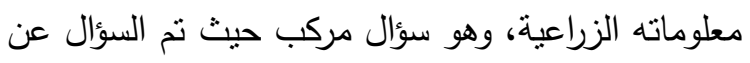
التعرض لمصادر المعلومات الزراعية وكانت الإجابة

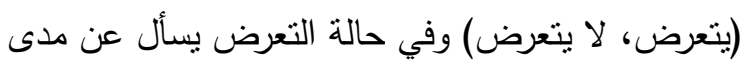

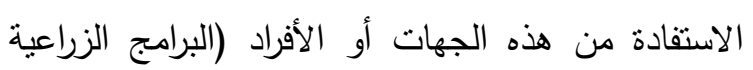

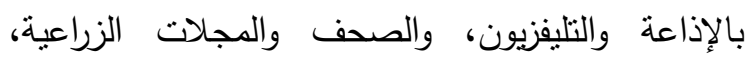
والنشرات الإرشادية، والعاملون بشروعات التشات التتمية

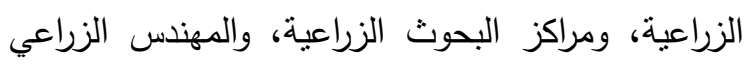

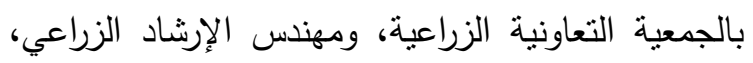

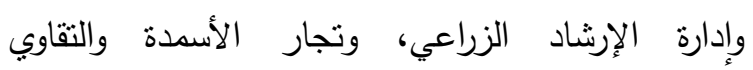

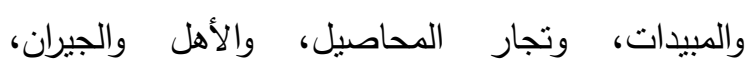
والإنترنت) وكانت الإجابة درجة استفادة (كبيرة،

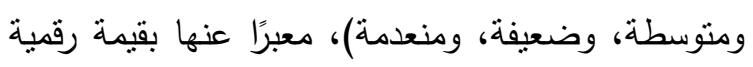

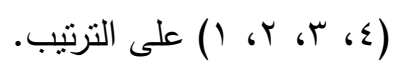

ثنانيًا: تميز الأداء الإشادي للعاملين بالارشاد الزراعي بمنطقة البحث: تم تناول تميز الأداء الإرشادي للعاملين بالإرشاد الزراعي

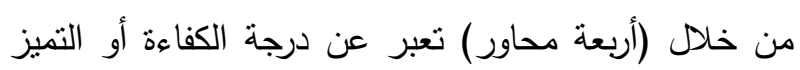

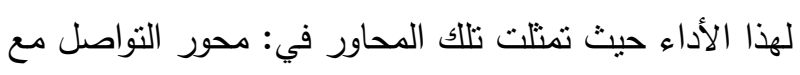
المزارعين، ومحور فعالية المشاركات السابقة في أنشطة الأنة

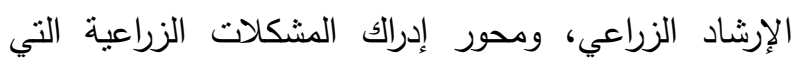

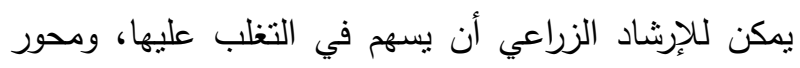

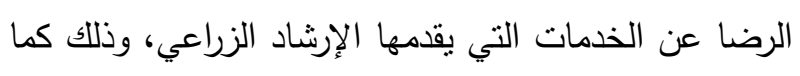
يلي: 
الحيازة المزرعية، والخبرة الزراعية، والخبرة الإرشادية، وعضوية المنظمات الرسمية، والتعرض لمصادر المعلومات

الزراعية).

لتحقيق الهدف الرابع تم وضع الفرض النظري العام الثاني والذي ينص على " نوجد علاقة بين درجة واقع الذكاءات المتعددة لدى العاملين بالإرثاد الزراعي بمحافظة الوادي لئي الجديد وبين المتغيرات المستقلة المدروسة".

ولإختبار هذا الفرض العام تم وضع ثمانية فروض احصائية احصائية (من ^- 10 1) نتنرك في النص التالي: "لا توجد علاقة بين درجة الكفائة أو الأداء الظاهري لواقع الذكاءات المتعددة لاى العاملين بالإرشاد الزراعي المبحوثين بمنطقة البحث وبين المتغيرات المستقلة المدروسة"، وهي: السن، ودرجة التعليم، وحجم الحيازة المزرعية، والخبرة الزراعية، والخبرة الإرشادية، وعضوية المنظمات الرسمية، ودية والتعرض لمصادر المعلومات الزراعية، وتميز الأداء الإرشنادي.

جمع البيانات:

جمعت البيانات النهائية لهذا البحث عن طريق المقابلة الشخصية للمبحوثين من العاملين بالارشاد الزراعي بمنطقة

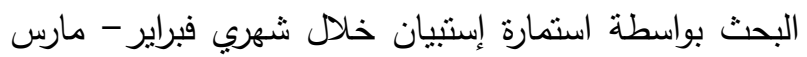
ا Y · r، وبعد الانتهاء من جمع البيانات تم تفريغها وجدولتها.

\section{أدوات التحليل الاحصائي:}

أُُتخدم في تحليل بيانات هذا البحث معامل الإرتباط البسيط لبيرسون لإختبار العلاقة بين درجة واقع الذكاءات

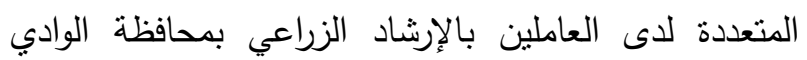

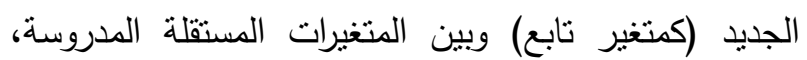
ودرجة تميز الأداء الإششادي للعاملين بالإرشاد الزراعي بمنطقة البحث (كمتغير تابع) ومتغيراتهم المستقلة المدروسة، هذا بالإضافة إلي الحصر العددي والعرض الجدولي بالتكرار والنسب المئوية، والمنوسط الحسابي، والإنحراف المعياري،

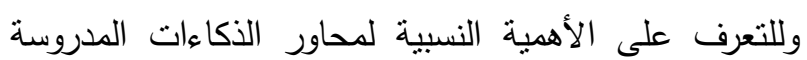

ثالثًا: الأكاءات المتعددة لاى العاملين بالإرشاد الزراعي بمنطقة البحث: تم تصميم مقياس للكفاءة أو الأداء الظاهر للذكاءات المتعددة، وتم اعنماد السبعة ذكاءات المناسبة للبحث من من الثمانية التي حددها جاردنر، والذكاءات السبعة هي: (الذكاء الاجتماعي، والذكاء اللغوي، والذكاء الحركي، والذكاء المنطقي/ الرباضي، والذكاء التخيلي، والذكاء الطبيعي/ البيئي، والذكاء الشخصي/الذاتي)، حيث تم استبعاد الذكاء الموسيقي. وقد نم صياعة عدد من العبارات (بـ عبارة)، تعبر عن كل ذكاء من تللك الذكاءات السبعة المدروسة وتراوحت عبارات مقياس كل ذكاء بين (0- ^) عبارات.

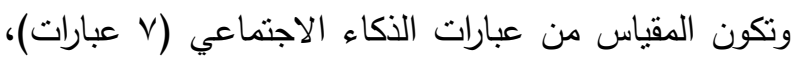
والذكاء اللغوي (0 عبارات)، والذكاء الحركي (0 عبارات)،

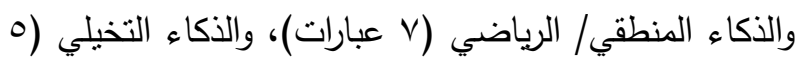
عبارات)، والذكاء الطبيعي/ البيئي (7 (7 عبارات)، والذكاء الثخصي/الذاتي (^ عبارات). تم الإجابة على نلك العبارات وفقًا لمقياس ليكرت المعدل (أوافق، لحد ما، لا أوافق)، معبرًا عنها بقيم رقمية (T، Y، ( ) على الترتيب. وتم تجميع درجات المبحوث في كل من الذكاءات السبعة وذلك لحساب درجة الكفاءة أو الأداء الظاهر للاككاءات المتعددة للمبحوثين من العاملين بالإرشاد الزراعي بمنطقة البحث.

\section{الفروض البحثية}

لتحقيق الهدف الثالث تم وضع الفرض النظري العام الأول والذي ينص على " توجد علاقة بين درجة تميز الأداء

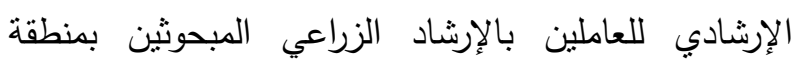
البحث ومتغيراتهم المستقلة المدروسة.

ولإختبار هذا الفرض العام تم وضع سبعة فروض

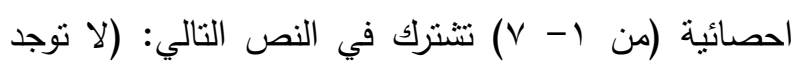
علاقة معنوية بين درجة تميز الأداء الإرشادي للعاملين بالإرشاد الزراعي المبحوثين بمنطقة البحث ومتغيراتهم المستقلة المدروسة"، وهي: السن، ودرجة التعليم، وحجم 
مؤهلهم الدراسي عالي، وكانت السمة الغالبة في التخصص

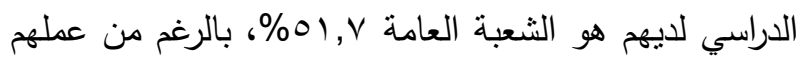

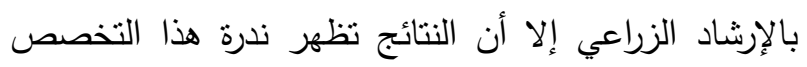

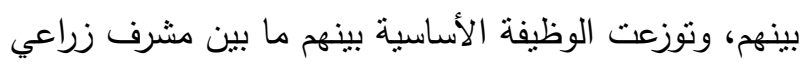

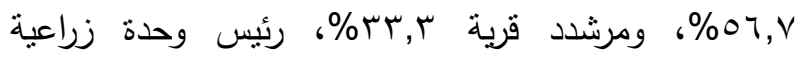

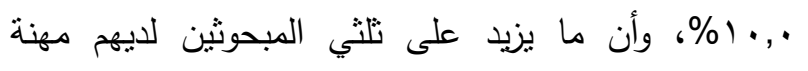

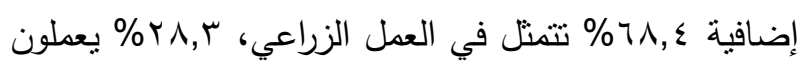

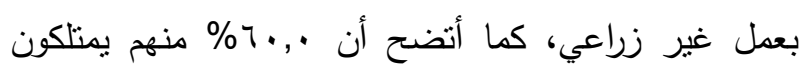

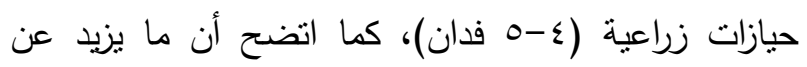

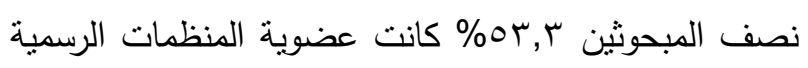

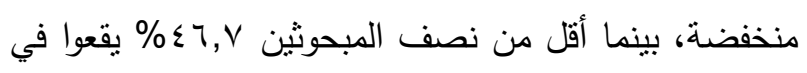
الفئة متوسطة درجة التعرض لمصادر المعلومات الزراعية.
استخدم المتوسط الحسابي المرجح (مج س و / مج و) حيث (س) تمثل التكرار،(و) تمثل الأوزان المختلفة لترتيب

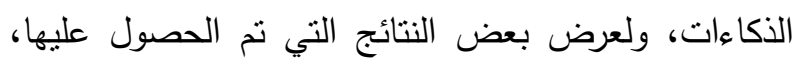
وذللك بإستخدام الحاسب الآلي لبرنامج الحزمة الإحصائية

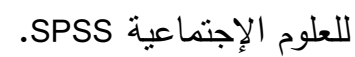

\section{وصف عينة البحث:}

أظهرت النتائج بالجدول رقم (1) أن ما يقارب ثلثي

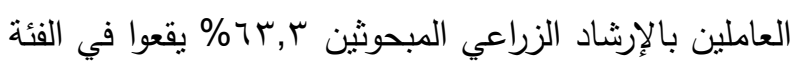
العمرية (0-0 أقل من ·r سنة)، بمعنى تواجد الخبرات الكافية لديهم ولكن في خلال أقل من عثرة سنوات سيحالون

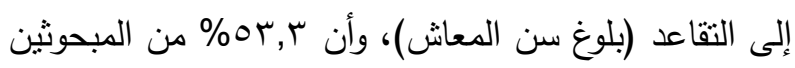

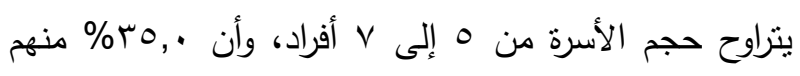

جدول ا ـ توزيع المبحوثين وفقًا لخصائصهم الثخصية المدروسة

\begin{tabular}{|c|c|c|c|c|c|}
\hline$\%$ & 1. & الخصائص الثخصية المدروسة & $\%$ & भ. & الخصائص الثخصية المدروسة \\
\hline & & r-درجة التعليم & & & 1- السن \\
\hline $70,$. & rq & 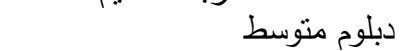 & $7, \mathrm{~V}$ & $\varepsilon$ & أقل من •؛ سنة \\
\hline$M, V$ & 19 & جامعى & $r \cdot, \cdot$. & in & (. - - .0 ) سنة \\
\hline \multirow[t]{2}{*}{$r, r$} & r & ماجستير فأكثر & 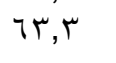 & rᄉ & (7. 0.0 (7. \\
\hline & & & & & شعبة عامة بام- التخصص الدراسي \\
\hline $\begin{array}{l}\lambda, r \\
0,\end{array}$ & r & وقباتين نيات & $\begin{array}{l}01, v \\
11, v\end{array}$ & $\begin{array}{l}r \\
v\end{array}$ & شتصبة عاملة اراضي \\
\hline \multirow[t]{3}{*}{$r, r$} & r & تعاون زراعي & $11, \mathrm{~V}$ & $\mathrm{v}$ & إنتاج حيواني \\
\hline & & & $\Lambda, r$ & ० & \\
\hline & & ه- العمل الاضافى & & & ع ع - الوظيفة \\
\hline$r, r$ & r & بدون & $07, \mathrm{~V}$ & $\Gamma \varepsilon$ & مشرف زراعى \\
\hline$\uparrow \Lambda, \varepsilon$ & « & زراعى & r r r & $r$. & مرشد زراعي \\
\hline \multirow[t]{2}{*}{ rA, r } & iv & غير زٍ & $1 \cdot, \cdot$ & 1 & رئيس وحدة زراعية \\
\hline & & 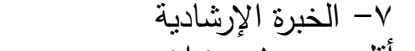 & & & الخبرة الزراعية \\
\hline$\{7, \vee$ & rA & أقل من · ا سنوات & $11, \mathrm{~V}$ & v & أقل من 10 سنة \\
\hline 17,7 & 1. & ) (r. (r. (r) سنة & rY, $\varepsilon$ & 14 & (10 - . (T) سنة \\
\hline \multirow[t]{2}{*}{$\mathrm{r}, \mathrm{V}$} & r & 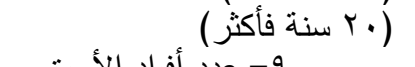 & 70,9 & $\varepsilon$. & 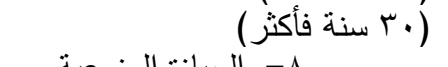 \\
\hline & & 9- جـ عدد أفراد الأسرة & & & يا بـ الحيازة المزرعية \\
\hline ro,. & 10 & (أقل من ه أفراد) & $11, v$ & v & 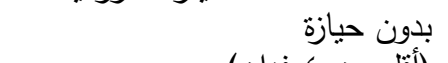 \\
\hline Or,T & rr & (أفراد) & 17,7 & 1. & (أقل من ؟ فدان) \\
\hline \multirow[t]{3}{*}{$r i, v$} & 14 & (فراد فأكثر ) & т.,. & ז & ( ع ع-7 فدان ) \\
\hline & & & $11, \mathrm{~V}$ & $v$ & جا فدان فأكثر \\
\hline & & المعلومات الزراعية لمصادر & & \multicolumn{2}{|c|}{ 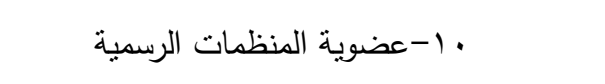 } \\
\hline$r \wedge, r$ & זr & منخفض ( أقل من بَ درجة) & or, ₹ & ru & منخفض (أقل من 9 درجة) \\
\hline$\leq 7, v$ & rA & 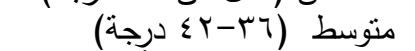 & $r \wedge, r$ & iv & متوسط (9- ال (1 درجة) \\
\hline $10,$. & 9 & مرتفع (rأ درجة فأكثر) & $1 \lambda, r$ & 11 & مرتفع (11 درجة فأكثر) \\
\hline
\end{tabular}




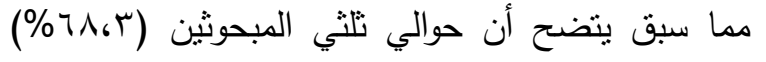

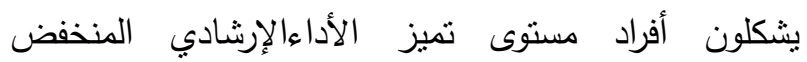

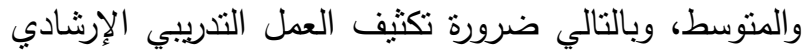

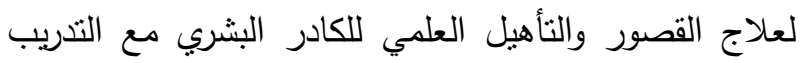
المستمر للعاملين بالارشاد الزراعي المبحوثين بمنطقة البحث.

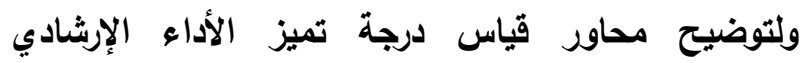
للعاملين بالإششاد الزراعي للمبحوثين: يمكن عرض النتائج البحثية الخاصة بمحاور قياس تميز الأداء الارشادي للعاملين بالارشاد الزراعي المبحوثين علي النحو التالي والموضحة

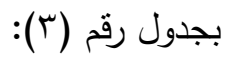

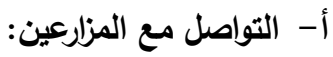

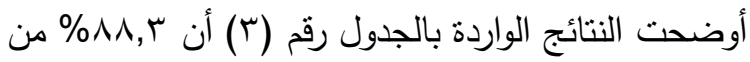

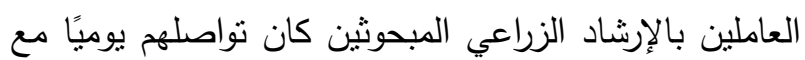

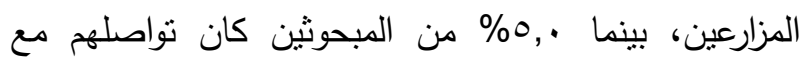

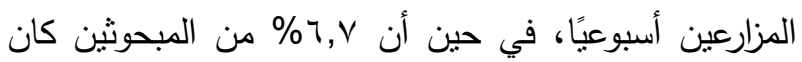

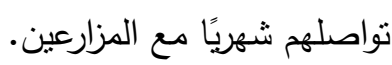
ب- فعالية المشاركة في أنثطة الإرشاد الزراعي:

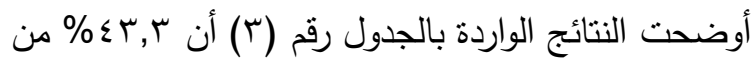
العاملين بالإرشاد الزراعي المبحوثين كانت لديهم درجة منخفضة من فعالية المشاركة في أنشطة الإرشاد الزراعي،

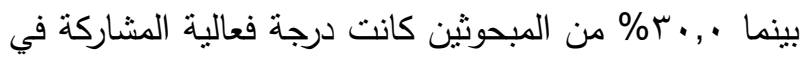

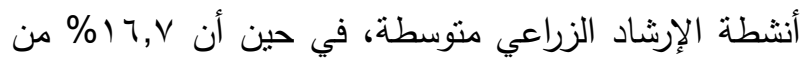
المبحوثين كانت درجة فعالية المشاركة في أنشطة الإرشاد

$$
\text { الزراعي للديهم مرتفعة. }
$$

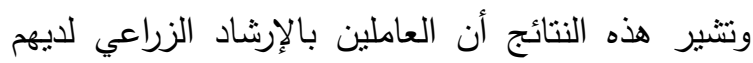

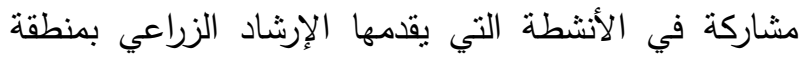
البحث بالمنطقة ولكن يتمايز بعض الأفراد بأنهم أكثر فاعلية في تتفيذ هذه الأنشطة ولا يكتفون بمجرد المشاركة الصورية

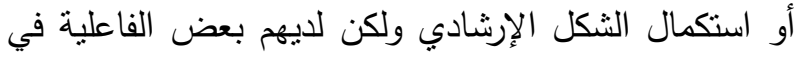

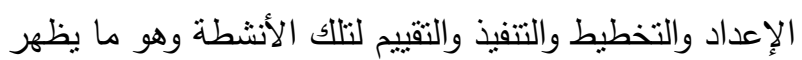

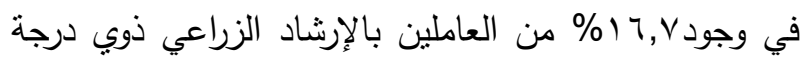

\section{النتائج البحثية}

$$
\text { يمكن عرض نتائج البحث علي النحو التالي: }
$$

أولاً: التعرف على واقع تميز الأداء لاى العاملين بالإرشاد الززاعي في محافظة الوادي الجديد. نم نتاول تميز الأداء الإرشادي للعاملين بالإرشاد

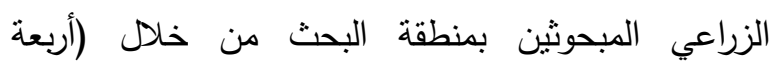

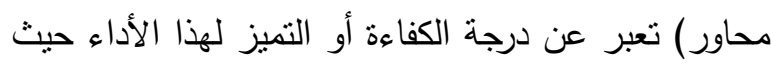
تمثلت تلاك المحاور في: محور التواصل دمع المزارعين، ومحور فعالية المشاركات السابقة في أنثطة الإرشاد

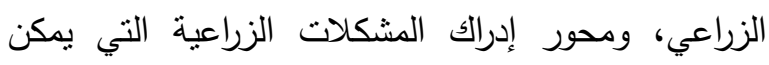

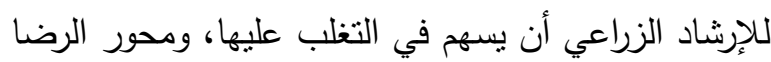
عن الخدمات التي يقدمها الإرشاد الزراعي. الارجة الكلية لواقع تميز الأداء الإرشادي للعاملين

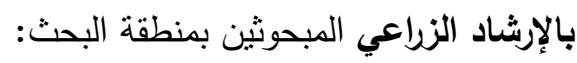
أثنارت النتائج البحثية إلى أن القيم الرقمية المعبرة عن لئن

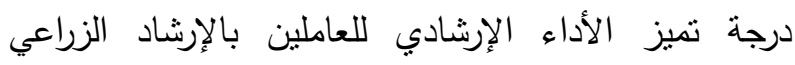
المبحوثين قد تراوحت بين(

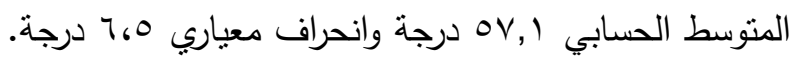

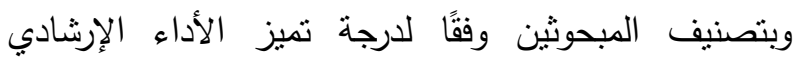
للعاملين بالإرشاد الزراعي إلى ثلاث فئات فبلغت نسبة ذوي الإني

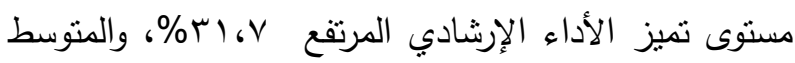

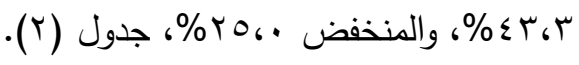

\begin{tabular}{|c|c|c|}
\hline$\%$ & التكرار & 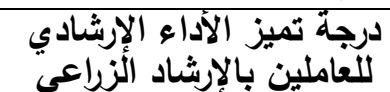 \\
\hline Yo,. & 10 & نيخفضة (أقل من ك درجة) \\
\hline$\varepsilon r, r$ & $\overline{Y T}$ & متوسطة (ب- (اך درجة) \\
\hline 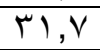 & 19 & مرتفعة ( آح درجة فأكثر) \\
\hline $1 \ldots$ & 7. & الاجمالى \\
\hline
\end{tabular}
جدولr. توزيع المبحوثين وفقًا لارجة تميز الأداء الإرشادي بمنطقة البحث

الصدرر : نتائج التحليل الاحصائي لعينة البحث 
التخلب عليها، وقد يُعزى ذلك إلى ضعف نشاط الإرشاد

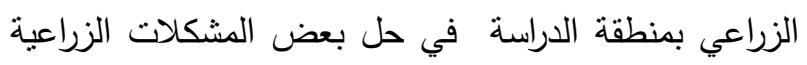
التي تواجه الزراع بمنطقة البحث.

د- الرضا عن الخدمات التي يقدمها الإششاد الزراعي:

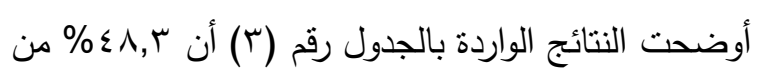

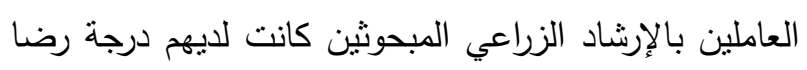

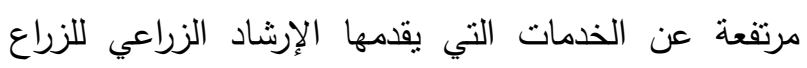

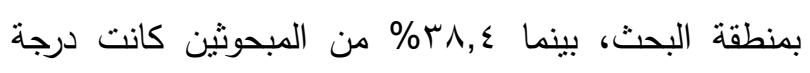

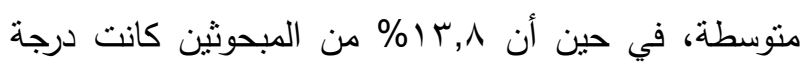
رضاهم منخفضة.

يتضح مما سبق أن ما يزيد عن نصف المبحوثين

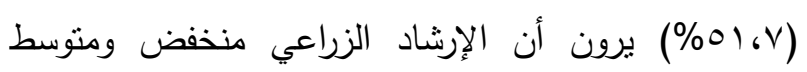

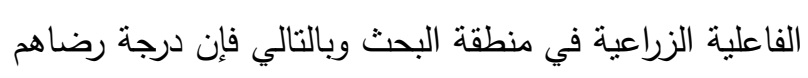

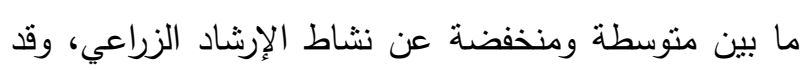

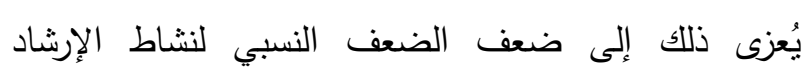

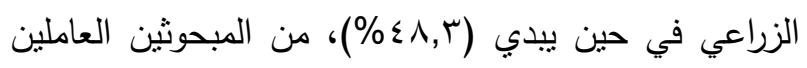

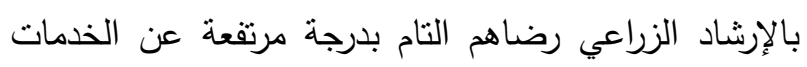
التي يقدما الإرشاد الزراعي بمنطقة البحث.
مرتفعة من الفعالية في الأنثطة السابقة للإرشاد الزراعي

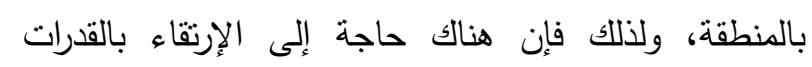
المهنية والوظيفية للعاملين بالإرشاد الزراعي الماتئية المبحوثين بمنطقة البحث من خلال تكثيف البرامج التنريبية لتنمية وبناء القدرات الإرشادية وكنلك التتسيق والتعاون مع الجهات التهات التهات البحثية بالجامعات والمراكز البحثية مما يزيد من تلإك القدرات ويزيد من فاعلية تلك المشاركات.

ج- إدراك المشكلات الزراعية التي يمكن للإرشاد الزراعي أن يسهم في التظلب عليها:

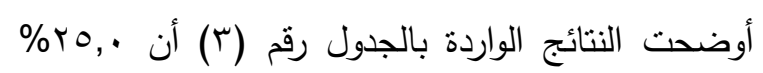

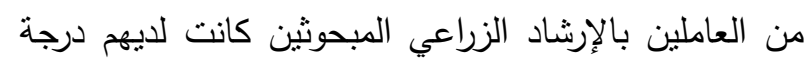

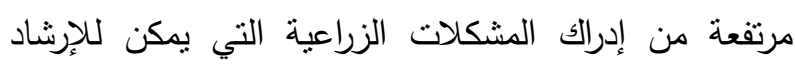

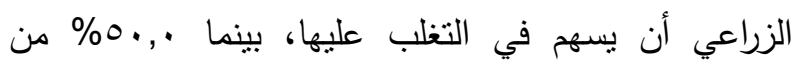

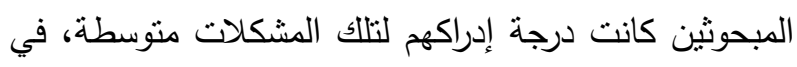

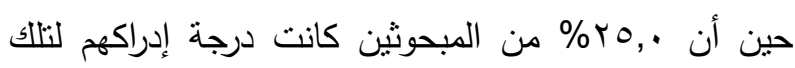

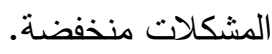

يتضح مما سبق أن نصف المبحوثين من العاملين

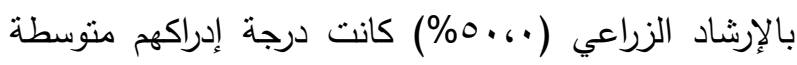

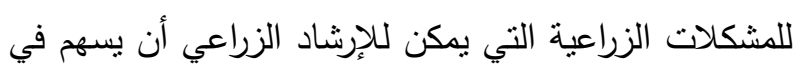

جدول r. توزيع المبحوثين وفقًا لدرجات محاور تميز الأداء الإرشادي بمنطقة البحث

\begin{tabular}{|c|c|c|c|c|}
\hline$\%$ & ๆ. $=\dot{0}$ & $\%$ & ४ & 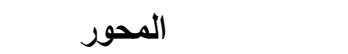 \\
\hline & \multicolumn{3}{|l|}{ * فعالية المشاركة فى أنشطة الإرشاد الزراعى } & * النواصل مع المزارعين \\
\hline$\varepsilon r, r$ & منخفضة (أقل من ^ درجة) & $\Lambda \wedge, r$ & or & 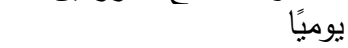 \\
\hline$r \cdot, \cdot$ & متوسطة (ي- • ا درجة) & 0, & $r$ & اسبوعيًا \\
\hline $17, \mathrm{~V}$ & مرتفعة ( · ( درجة فأكثر) & $7, \vee$ & $\varepsilon$ & شَهريًا \\
\hline $1 \ldots$ & 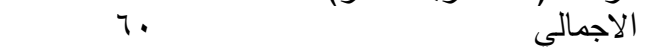 & $1 \ldots$ & 7. & 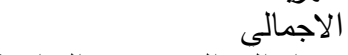 \\
\hline \multicolumn{5}{|c|}{ • • الرضا عن الخدمات التي يقدمها الإرشاد الزراعي } \\
\hline r & منخفضة (أقل من الس درجة) $\quad$ $\quad$ & ro,. & 10 & منخفضة (ألّل من ج درجة) \\
\hline ऍ^,乏 & متوسطة ( آT-V- درجة) & $0 ., \cdot$ & r. & منتسطة (1َ- 11 درجة) \\
\hline$\varepsilon \wedge, r$ & مرتفعة ( r د درجة فأكثر) & ro, & 10 & مرتفعة ( 'ال درجة فأكثر) \\
\hline $1 \ldots$ & 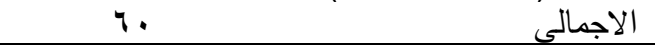 & $1 \cdots$ & 7. & الاجمالى \\
\hline
\end{tabular}


حسابي مرجح قدره (Tr,0 درجة)، ويأتي في الثرتيب الرابع

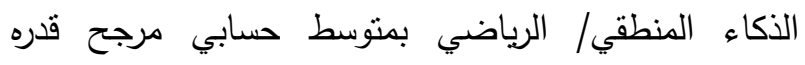

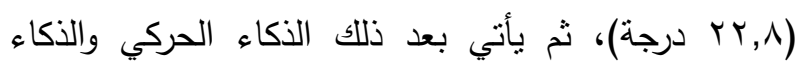

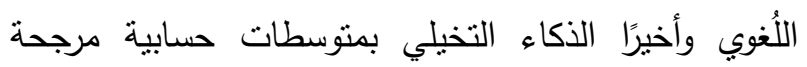

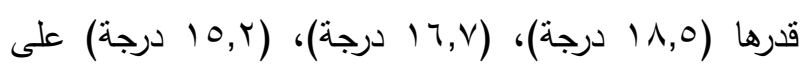

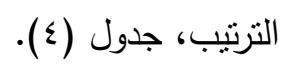

وتثير هذه النتائج إلى أن الذكاء الاجتماعي منل أسبقية

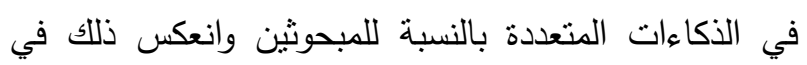

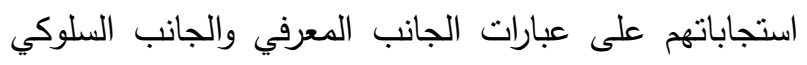

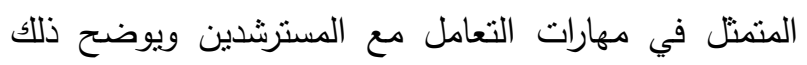

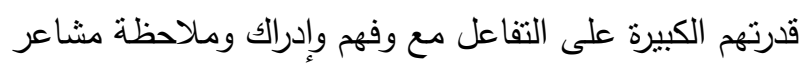

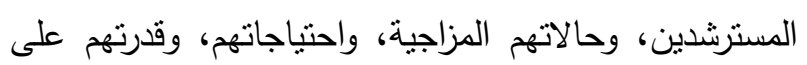

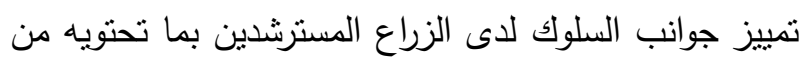

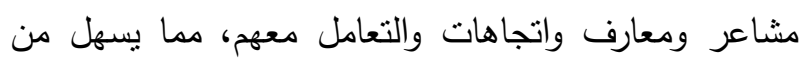

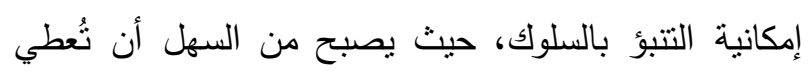
الناس ما بريدون إذا كنت ندرك ما هو وتعرفه دون نزاعات وخلافات، وهذا الجانب قد يوضح صورة إنتزاج المبحوثين

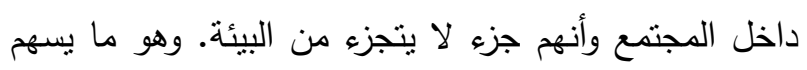

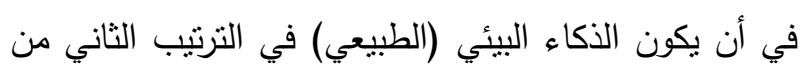

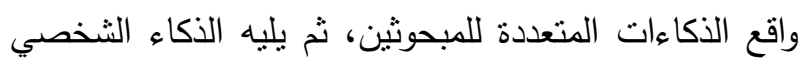

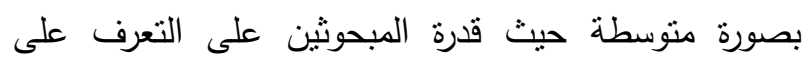
مكامن القوة والضعف لليهم وبالتالي اتخاذ القرارات المناسبة

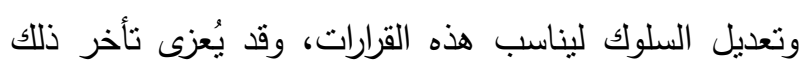

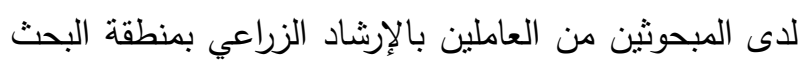

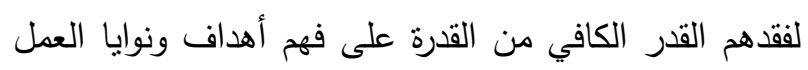
الإرشادي. ومن الطبيعي وفقًا للمشاهدات أن يكون الفاء الفاء

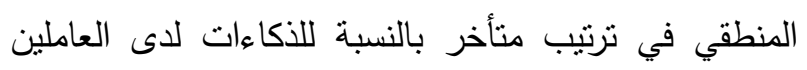

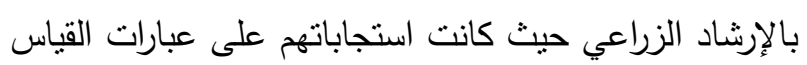

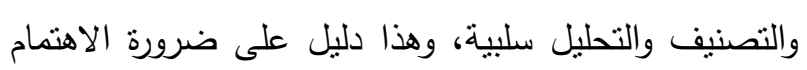
أكثر بتتمية الذكاء المنطقي لاى المبحوثين.
ثنائًا: التعرف على واقع الذكاءات المتعددة لاى المبحوثين من العاملين بالإرشاد الزراعي في محافظة الوادي الجديد. تزداد دلالة الذكاء وقدات التفكير في عصر المعلومات والاقتصاد القائم على المعرفة، وبالدتل فإن جوانب القصور في في القان هذه القدرات تضع حدودًا لقدرة الإنسان على مواجهة تحديات هذا

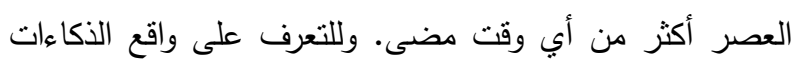

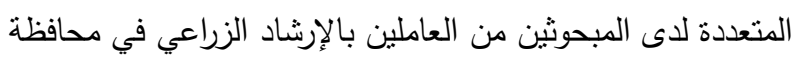
الوادي الجديد، نم ذلك من خلال درجة الكفاءة أو الأداء الظاهري لواقع الذكاءات المتعددة للمبحوثين من العاملين بالإرشاد الزراعي

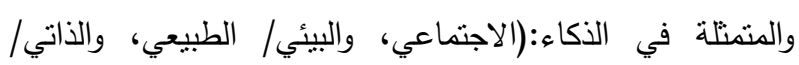
الثخصي، والمنطقي/ رياضي، والحركي، واللغوي، والتخيلي). جدول ؛ . ترتيب المبحوثين حسب محاور الأكاءات المتعددة

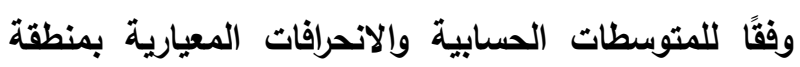

\begin{tabular}{|c|c|c|c|c|}
\hline الترتيب & المستوسي & اللُعياري & الحسابي & الذكاء \\
\hline 1 & YV $6 V$ & $Y, Y \varepsilon$ & IN,Tr & اجتماعي \\
\hline r & $T \leqslant, Y$ & $1, V Y$ & Ir,r. & \\
\hline$r$ & $r r, O$ & $r, 11$ & $\mid V, \varepsilon \wedge$ & \\
\hline$\varepsilon$ & $r, \Lambda$ & $\varepsilon, V Y$ & $10, \pi r$ & \\
\hline 0 & 11,0 & $r, \cdot r$ & 11,74 & حركى \\
\hline 7 & 17,5 & $r, Y V$ & $1,0 \wedge$ & لغوي \\
\hline \multirow[t]{2}{*}{ v } & $10, r$ & $1, V Y$ & $V, T$ & تخيلي \\
\hline & $r \varepsilon, r$ & $1 \varepsilon, r Y$ & $Q Y, Y T$ & ألذجماءلي \\
\hline
\end{tabular}

وأظهرت النتائج الواردة بالجدول رقم (ع) أنه بمكن ترتيب المبحوثين للاءكاءات المتعددة وففًا للمنوسطات الحسابية المرجحة على النحو النالي: الذكاء الاجتماعي في الترتيب

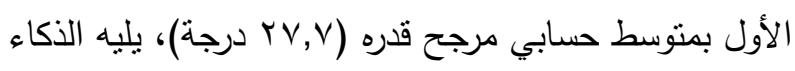

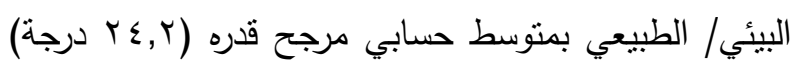

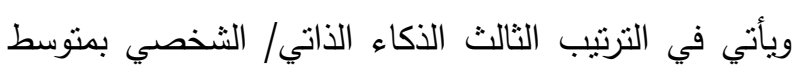


جدول ه . توزيع المبحوثين وفقًا لمحاور الأكاءات المتعددة

\begin{tabular}{|c|c|c|c|c|c|}
\hline \multicolumn{5}{|c|}{ ه- الأكاء الحركي } & 1- الأكاء الاجتماعي \\
\hline$\%$ & عدد & مستوى الكفاءة أو الأداء الظاهري & $\%$ & عدد & مستوى الكفاءة أو الأداء الظاهري \\
\hline r $1, Y$ & $\pi$ & منخفض (أقل من • ا درجة) & $\cdot, \cdot$ & . & منخفض (أقل من || درجة) \\
\hline$v 1,7$ & $\varepsilon r$ & 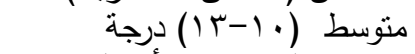 & L, & $1 \varepsilon$ & (1) (1) درجة \\
\hline $7, \mathrm{~V}$ & $\varepsilon$ & مرتفع (بَ آدرجة فأكثرَ) & $\vee T, V$ & $\leq 7$ & (10 درجة فأكثر ) \\
\hline $1 \ldots$ & 7. & 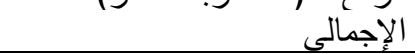 & $1 \ldots$ & 7. & נ \\
\hline \multicolumn{5}{|c|}{ צا - الأكاء اللغوي } & r- الأكاء البيئي/ الطبيعي \\
\hline$\%$ & عدد & مستوى الكفاءة أو الأداء الظّاهري & $\%$ & عدد & \multirow{5}{*}{ 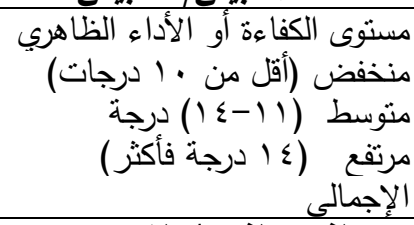 } \\
\hline $01, \mathrm{~V}$ & ו & منخفض (أقل من م درجات) & $1 \cdot, \cdot$ & \multirow{2}{*}{$\begin{array}{r}4 \\
r \\
\end{array}$} & \\
\hline$r \cdot, \cdot$ & 11 & \multirow{3}{*}{ (1) } & $r \wedge, r$ & & \\
\hline $1 \wedge, r$ & 11 & & $01, V$ & 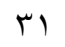 & \\
\hline $1 \ldots$ & 7. & & $1 \ldots$ & 7. & \\
\hline \multicolumn{5}{|c|}{ V - V الأكاء التخيلى } & r- الأكاء الأتى/ الشخصى \\
\hline$\%$ & عدد & مستوى الكفاءة أو الأداء الظاهري & $\%$ & عدد & \multirow{5}{*}{ 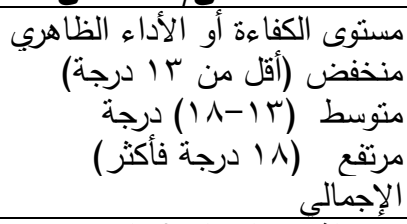 } \\
\hline $01, V$ & r & منخفض (أقل من ^ درجات) ري & $\cdot, \cdot$ & . & \\
\hline$\leqslant 0$, & rV & متوسط (1)-11) درجة & 70, & rq & \\
\hline$r, r$ & r & مرتفع ('ا درجة فأكثر) & ro,. & r) & \\
\hline \multirow[t]{7}{*}{$1 \ldots$} & 7. & 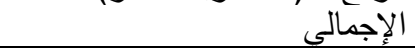 & $1 \ldots$ & 7. & \\
\hline & & & & & \multirow{6}{*}{ 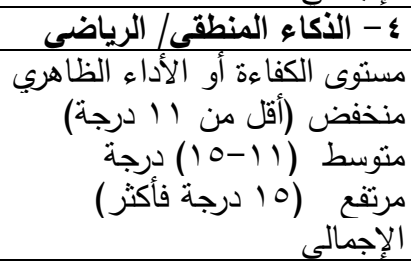 } \\
\hline & & & $\%$ & عدد & \\
\hline & & & ro,. & 10 & \\
\hline & & & $r^{\prime}, V$ & rו & \\
\hline & & & r, & r & \\
\hline & & & $1 \ldots$ & 7. & \\
\hline
\end{tabular}

المصدر : نتائج التحليل الاحصائي لعينة البحث

وفيما يلي عرضًا لأنواع الذكاء وفقًا للمحاور التالية:الكفاءة أو الأداء الظاهر للأكاء الإجتماعي:

تم تتاول هذا النوع من الذكاء من خلاء (أربعة محاور)

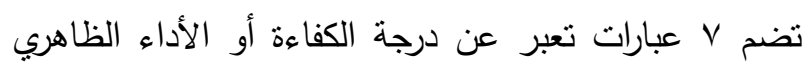
للاكاء الاجتماعي لاى المبحوثين من العاملين بالإرشاد الزراعي بمنطقة البحث حيث تمنلت تلك المحاور في: محور

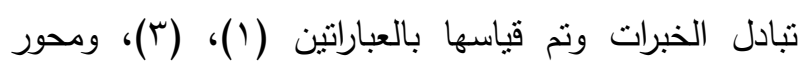

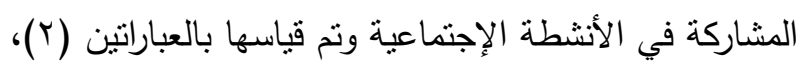

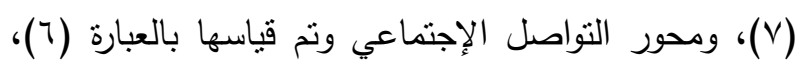

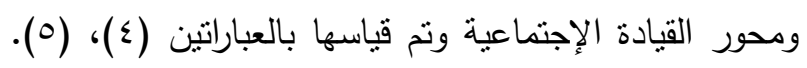

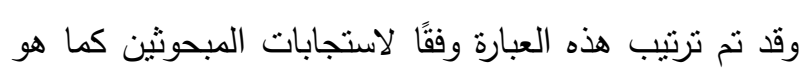
موضح بالجدول (؟).
كما أن الذكاء الحركي وهي القدرة للمرء على استخدام جسده بتمكن وكفاءة ومرونة واضحة والميل إلى أداء الأعمال والأنشطة اليدوية والذي من الهفترض وأن يتمانشي والثي مع البيئة

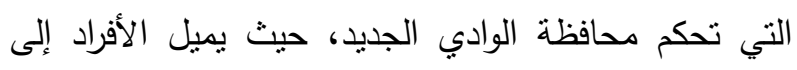

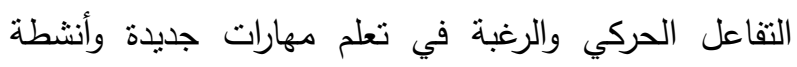

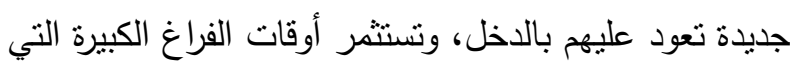

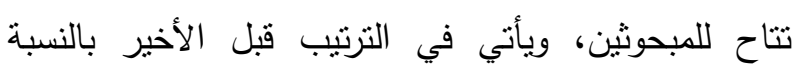

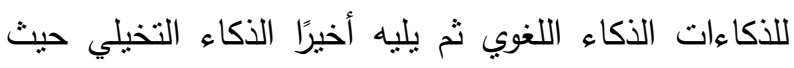

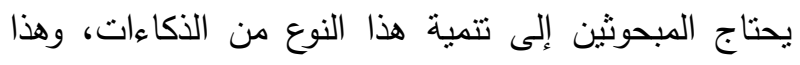

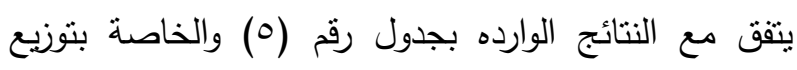

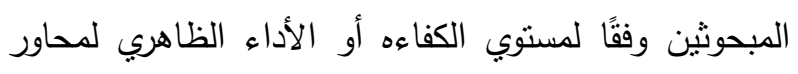

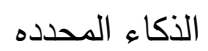


جدول 7.

\begin{tabular}{|c|c|c|c|}
\hline الترتيب & الاستجابة & المتوسط الحسابي المرجح & عبارات الذكاء الاجتماعي \\
\hline 1 & أوافق & $r \cdot, \cdot$ & خبرات التي اكتسبتها في عملي. \\
\hline r & أوافق & $r q, r$ & في نثاطات اجتماعية متعلقة بعملي أو في دور العبادة أو \\
\hline r & أوافق & $r \wedge, r$ & يأتنينى الززراع من الجيران إلى العمل لأقدم لهم النصيحة. \\
\hline$\varepsilon$ & أوافق & $r V, r$ & 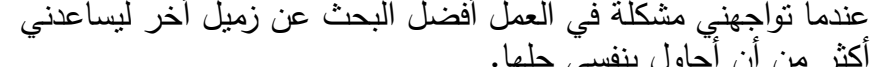 \\
\hline 。 & أوافق & $r_{0},$. & أُنا أعتبر نفسي قياديًا، أو هكذا يراني الآخرون. \\
\hline 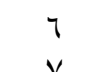 & 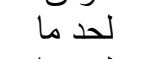 & $Y, \Lambda$ & أنا دائم الاتصآل بزملائي في الإدارات الزراعية بالوادي. . . \\
\hline $\mathrm{v}$ & لحد ما & r1,0 & أفضل قضاء وقتى مع الزملاء على أن أبقى وحيدا في البيت. \\
\hline
\end{tabular}

الدصدر : نتائج التحليل الاحصائي لعينة البحث

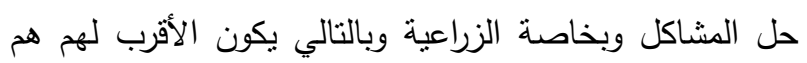

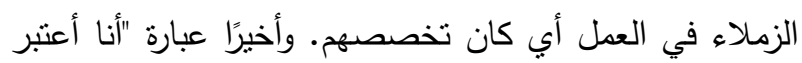

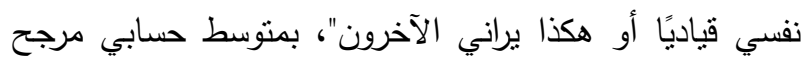
قدره (T, ع ب درجة). ويتضح كذللك أن هناك (عبارتين) على مقياس الذكاء (لاء

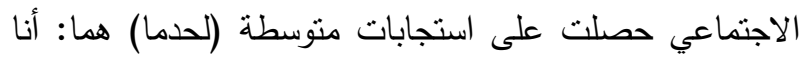

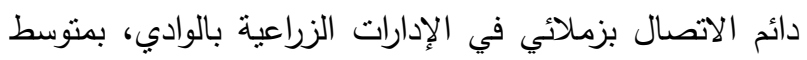

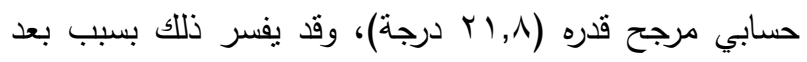

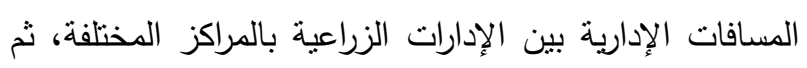

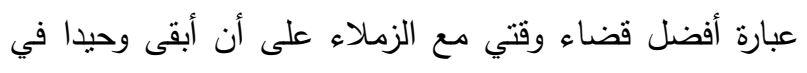

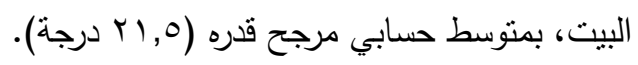
r- الكفاءة أو الأداء الظاهر للأكاء البيئي (الطبيعي): تم تتاول هذا النوع من الذكاء من خلال (ثلاثة محاور)

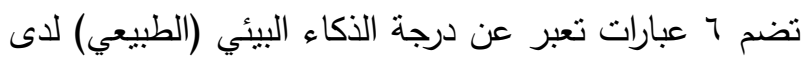
المبحوثين، وتمتلت نلك المحاور في: محور التمتع بتربية

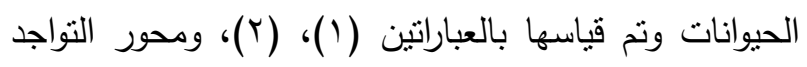

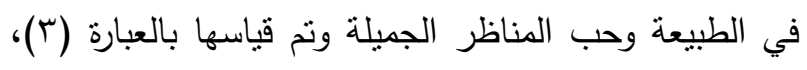
ومحور الترتيب والتتظيم والتسجيل وتم قياسها بالعباراتين

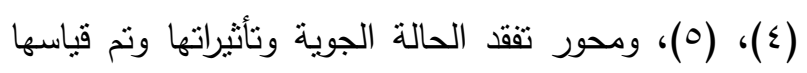
بعبارة رقم (†)، وقد تم ترتيب هذه العبارة وفقًا لاستجابات

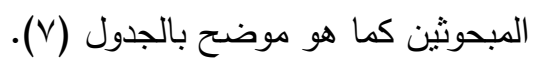

يتضح من ذلك الجدول أن أهم عبارات الكفاءة أو الأداء

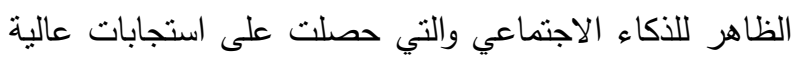

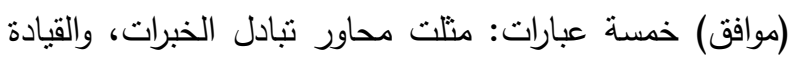
الإجتماعية، والمشاركة في الأنشطة الإجتماعية وهذه العبارات

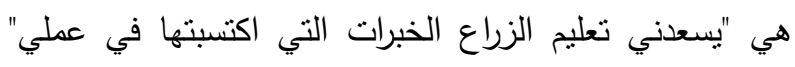

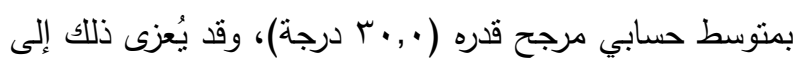
اعتماد معظم العاملين بالإرشاد الزراعي على الخبرات الميدانية

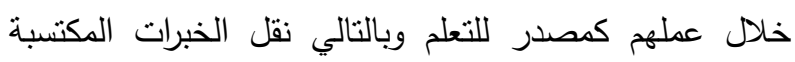

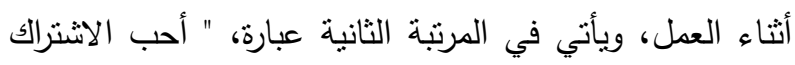

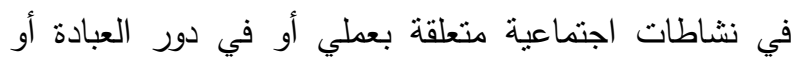

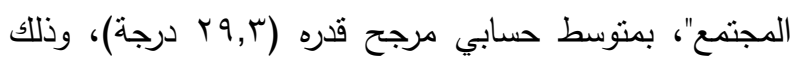

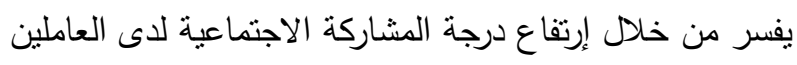

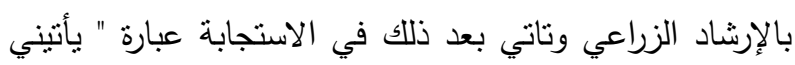

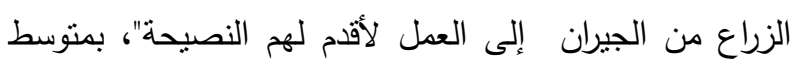

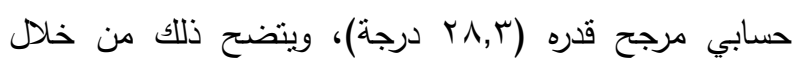

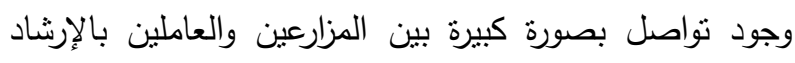
الزراعي من وجهة نظر الإرثاديين، ثم عبارة "عندما تواجهني بالإنياد مثكلة في العمل أفضل البحث عن زميل أخر ليساعدني أكثر

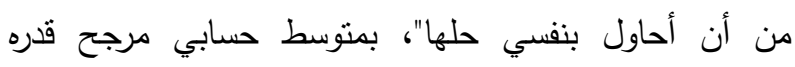

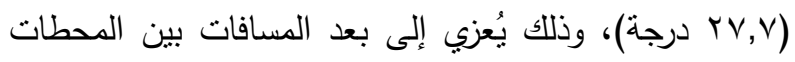

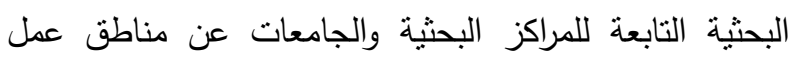

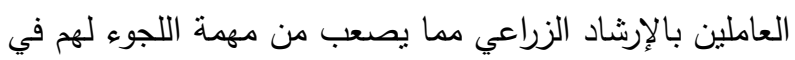


جدول V. ترتيب عبارات الذكاء البيئي وفقًا لاستجابات المبحوثين

\begin{tabular}{|c|c|c|}
\hline الترتيب & الاستجابة & المتوسط الحسابي المرجح \\
\hline 1 & موافق & $r_{0, \Lambda}$ \\
\hline r & موافق & $r_{0,0}$ \\
\hline r & موافق & ro,r \\
\hline$\varepsilon$ & لحد ما & $r, 0$ \\
\hline 0 & لحد ما ل ل ل & $1 \wedge, \wedge$ \\
\hline 7 & لحد ما & $1 \mathrm{~V}$, \\
\hline
\end{tabular}

عبارات الأكاء البيئي

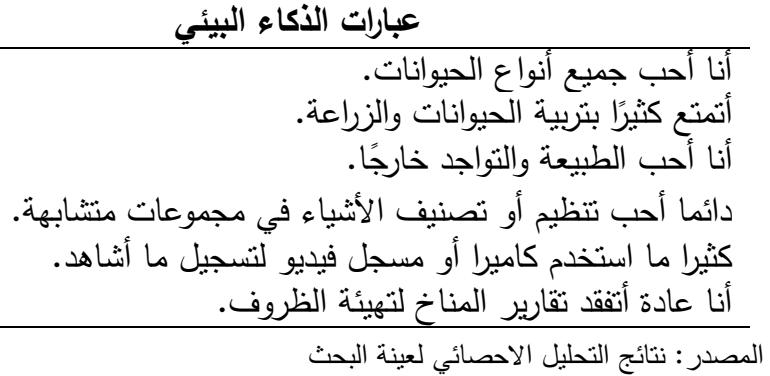

بمنوسط حسابي مرجح قدره (Y,0)، و (

بتضح من ذات الجدول أن نصف عبارات الكفاءة أو التزتيب، وتفقد الحالة الجوية وتأثيراتها، وكانت الاستجابات الأداء الظاهر للاكاء البيئي حصلت على استجابات عالية IV,· ) لها متوسطة (لحد ما) بمنتسط حسابي مرجح قدره (موافق) ثلاث عبارات: حيث كانت العبارات تدور حول درجة). محور التمتع بتربية الحيوانات، " أنا أحب جميع أنواع الكفاءة أو الأداء الظاهر للأكاء الأاتي (الثخصي):

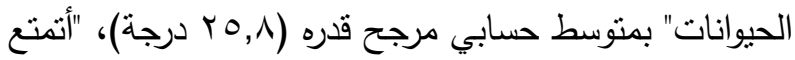
تم تتاول هذا النوع من الذكاء من خلال (أربعة محاور) كثيرًا بتربية الحيوانات والزراعة" بمتوسط حسابي مرجح قدره تضم ^ عبارات تعبر عن درجة الذكاء الذاتي لدى المبحوثين (ro,0 درجة)، ومحور التواجد في الطبيعة وحب المناظر تمثلت تلك المحاور في: محور التفكير والتخطيط الذاتي وتم الجميلة، " أنا أحب الطبيعة والتواجد خارجًا"، بمنوسط حسابي قياسه بالعباراتين (1)، (Y)، ومحور الهوايات والاهتمامات مرجح قدره (ro,r درجة)، وقد يعزي ذللك إلى الظروف ونم قياسه بالعباراتين (ب)، (ع)، ومحور الإرادة الذاتية وتم البيئية والتتوع البيئي الذي تتمتع به محافظة الوادي الجديد قياسه بالعباراتين (0)، (7)، ومحور تقدير الفرد لدرجة والذي بدوره يسهم في تتمية هذا النوع من الذكاء ويسنلزم الاستقلالية الحياتية وتم قياسه بالعباراتين (V)، (^). وقد تم ترتيب هذه العبارات وفقًا لاستجابات المبحوثين كما هو بالهاتين التواجد في تلك البيئة تتمية تلك المهارات الإنسانية. بينما أظهرت النتائج حيادية الاستجابة لدى المبحوثين من العاملين موضح بالجدول (^). بالإرشاد الزراعي لعبارات الدالة على الذكاء البيئي في محورين هما حيث محور الترتيب والتتظيم والتسجيل

جدول ^. ترتيب عبارات الذكاء الذاتي (الثخصي) وفقًا لاستجابات المبحوثين

\begin{tabular}{|c|c|c|}
\hline الترتيب & الاستجابة & لمتوسط الحسابي المرجح \\
\hline 1 & موافق & $r\urcorner$, \\
\hline$r$ & موافق & $r_{0,0}$ \\
\hline$r$ & لحد ما & $r r,$. \\
\hline$\varepsilon$ & لحد ما & YI, \\
\hline 0 & لحد ما & $r 1,1$ \\
\hline 7 & لحد ما & 19,1 \\
\hline V & لحد ما & 19,7 \\
\hline$\wedge$ & لحد ما & 11,0 \\
\hline
\end{tabular}
عبارات الأكاء الذاتي التي

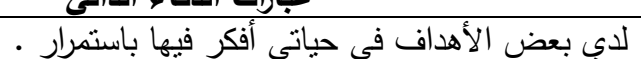

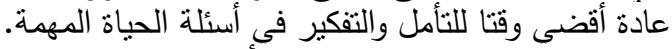
لدي اهتمامات وهوايات خاصة بي أحتفظ بها لفال النفسي.

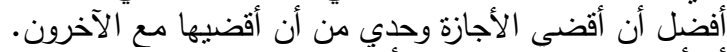

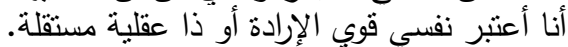

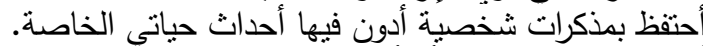

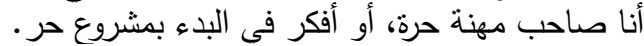

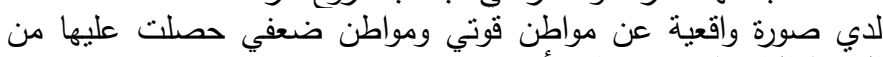

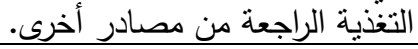


( ب, (درجة)، وأحتظظ بمذكرات شخصية أدون فيها أحداث

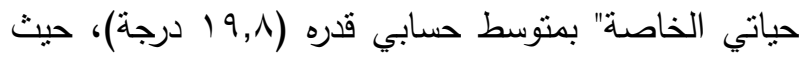

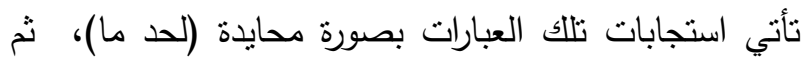
عبارتين لدحور تقدير الفرد لدرجة الاستقالاية الحياتية والتي

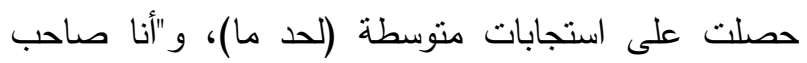

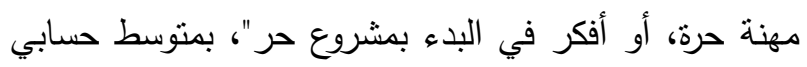
قدره (19,7 درجة)، و" لدي صورة واقعية عن مواطن قوتي الده ومواطن ضعفي حصلت عليها من التغذية الراجعة من درن

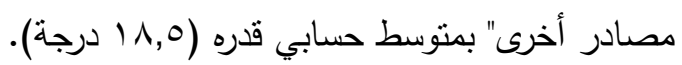
الكفاءة أو الأداء الظاهر للأكاء المنطقي (الرياضي): نم تتاول هذا النوع من الذكاء من خلال (ثلاثة محاور) تضم V عبارات تعبر عن درجة الذكاء المنطقي لدى المبحوثين تمثلت نلايك المحاور في: محور التفكير والتفسير

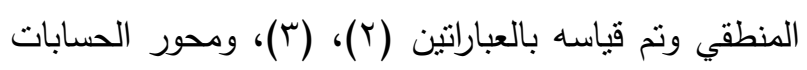

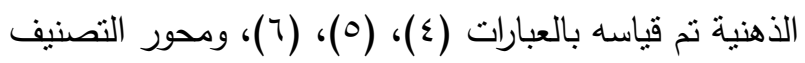

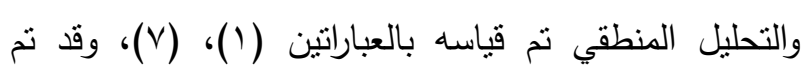

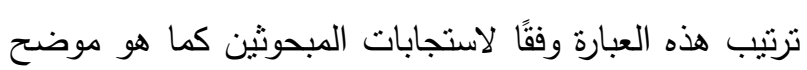

بالجدول (9).
يتضح من الجدول السابق أن أهم عبارة من عبارات

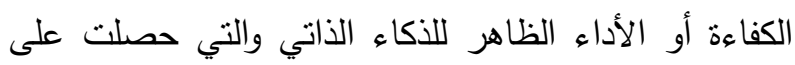

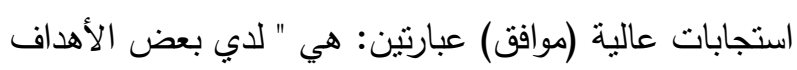

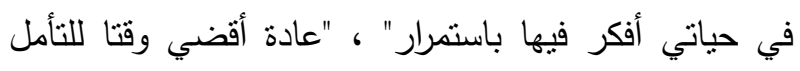

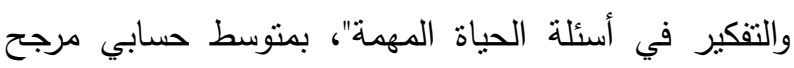

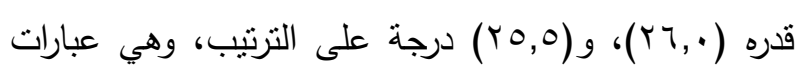

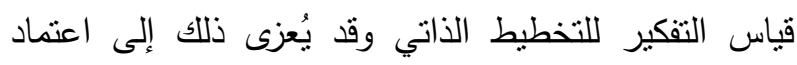

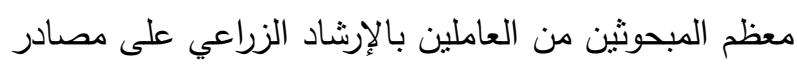

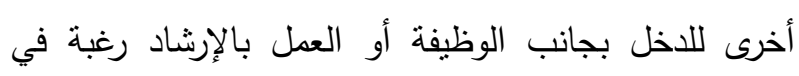

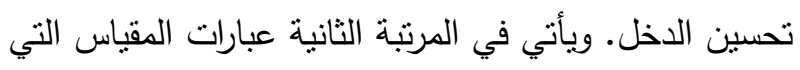

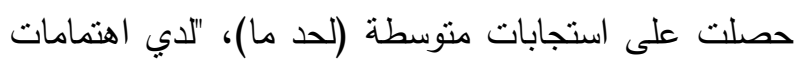

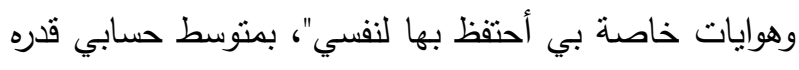

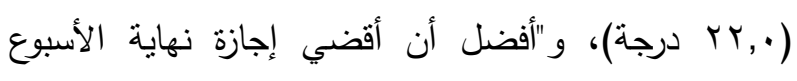

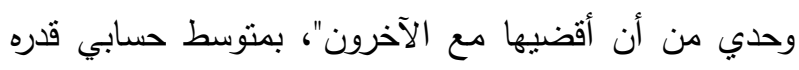

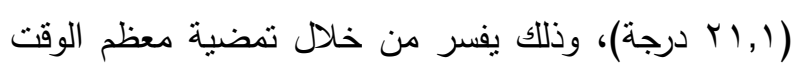

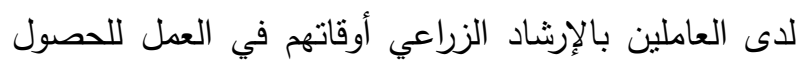

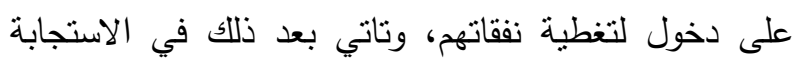

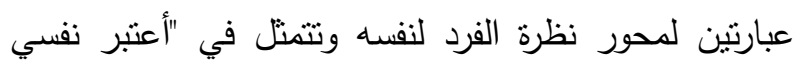
قوي الإرادة أو ذا عقلية مستقلة "، بمتوسط حسابي قدره فئري

جدول 9.

\begin{tabular}{|c|c|c|c|}
\hline الترتيب & الاستجابة & المتوسط الحسابي المرجح & عبارات الذكاء المنطقي \\
\hline 1 & موافق & $r 0, r$ & أنا أكتبتف أخطاء الناس في الأفعال والأقوال في عطهم أو في بيوتهم أو \\
\hline r & لحد ما & $r \leqslant, 0$ & يسرنى الآثغخال بحل الشكلات التى تتطلب تفكيرًا منطقيًا. \\
\hline r & لحد ما & $r, r$ & 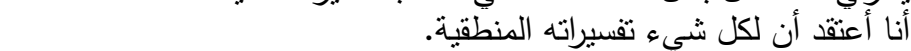 \\
\hline$\varepsilon$ & لحد ما & $r, r$ & أنا أستطيع الحساب في ذهني بسهولة . \\
\hline$\circ$ & 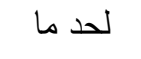 & $r_{1}, \cdot$ & الرياضياتِ و / أو العلوم كانت من المواد المفضلة عندي. \\
\hline 1 & لحد ما & $r \cdot, l$ & 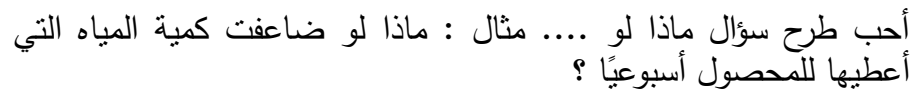 \\
\hline $\mathrm{v}$ & لحد ما & $17, r$ & معينة. بمزيد من الراحة عندما تقاس الأثشياء وتصنف و تحلل وتعطى كميات \\
\hline
\end{tabular}


والأقوال في عملهم أو في بيوتهم أو في مزارعهم، بمتوسط

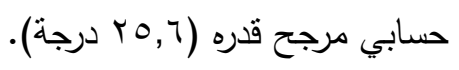

(الكفاءة أو الأداء الظاهر للاكاء الحركي (الجسدي): تم تناول هذا النوع من الذكاء من خلال (محورين)

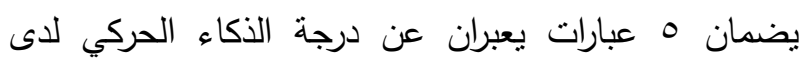
المبحوثين تمثلت في: محور النشاط البدني وقد نم قياسه

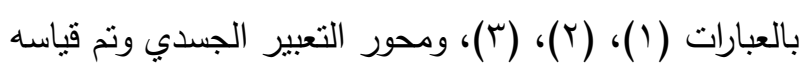

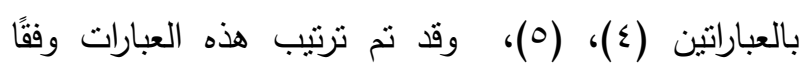
لاستجابات المبحوثين كما هو موضح بالجدول (• (1).،

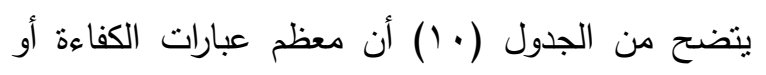

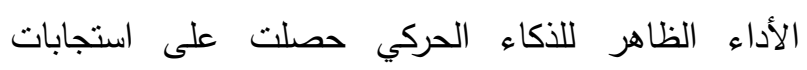

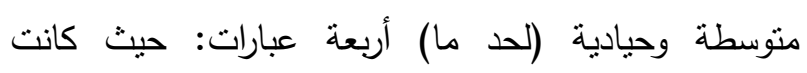

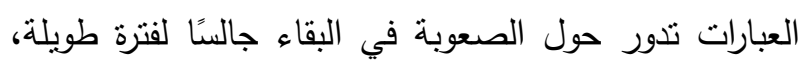

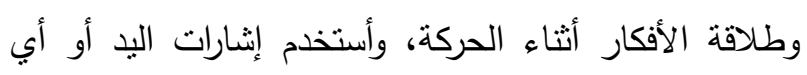

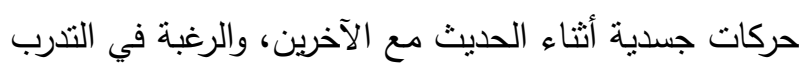

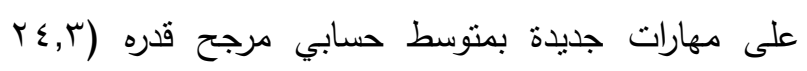

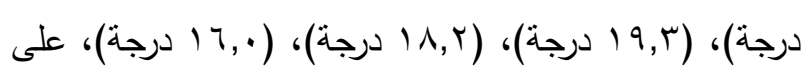

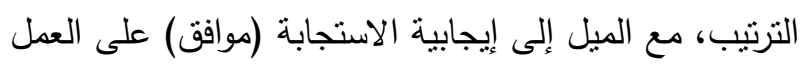

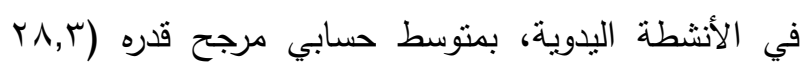

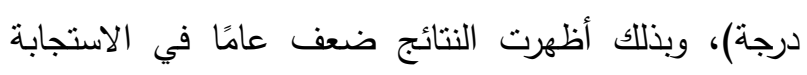
لادى المبحوثين من العاملين بالإرشاد الزراعي للعبارات الدالة

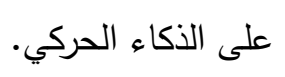

بتضح من ذلك الجدول أن معظم عبارات الكفاءة أو

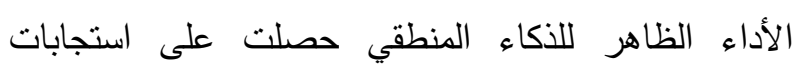

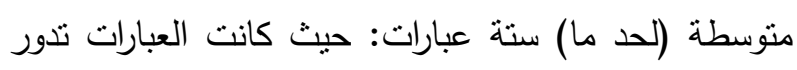
حول سلوك التفكير المنطقي في الأحداث والمشكلات كارت الهات

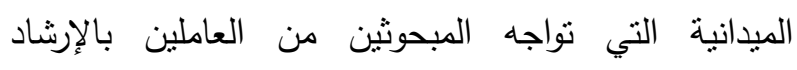
الزراعي، والرجوع إلى الإسلوب المنطقي في تفسير الظواهر بالرئر

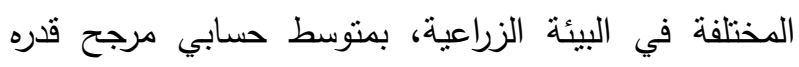

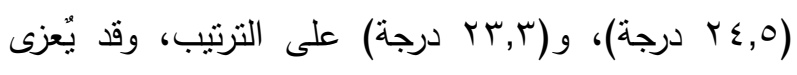
تفسير حيادية تلك الاستجابات إلى طبيعة المستوى التعليمي

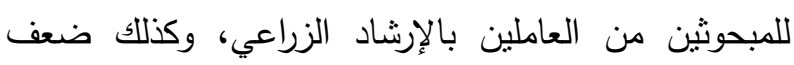

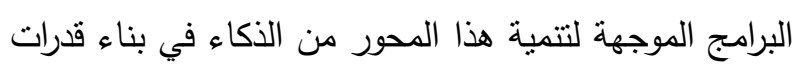
المبحوثين، ويؤكد ذلك استجابات المبحوثين في عباء لئارات

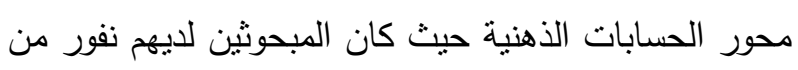

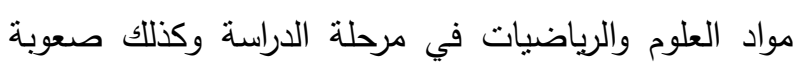

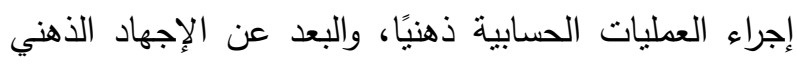
بالعمليات الحسابية والميل إلى التقديرات الوهمية التي أحيانًا

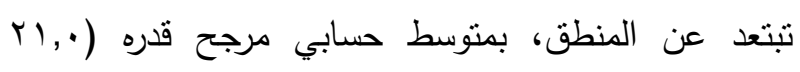

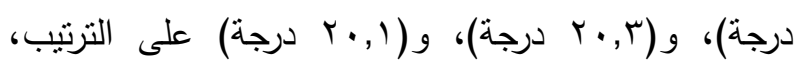

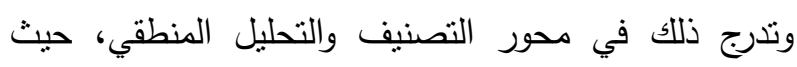
كانت استجاباتهم حيادية ويُبدون ضعف ولئن الثعور بالأهمية وعدم القدرة على قياس الأشياء وتصنيفها وتحليلها، بمتوسط بالئ

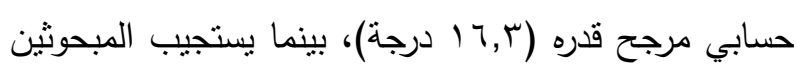
بالموافقة على قدرتهم على أكتثاف أخطاء الناس في الأفعال

جدول · ل ـ ترتيب عبارات الذكاء الحركي (الجسدي) وفقًا لاستجابات المبحوثين

\begin{tabular}{|c|c|c|}
\hline الترتيب & الاستجابة & متوسط الحسابي المرجح \\
\hline 1 & موافق & $r \wedge, r$ \\
\hline r & 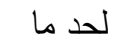 & $r \varepsilon, r$ \\
\hline$r$ & 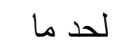 & $19, r$ \\
\hline$\varepsilon$ & 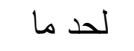 & $1 \Lambda, Y$ \\
\hline 0 & 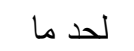 & $17,$. \\
\hline
\end{tabular}
عبارات الذكاء الحركي الإني أنا أحب أن أعمل في الأنشطة اليدوية. أجد صعوبة في البقاء جالسا لفترة طويلة.

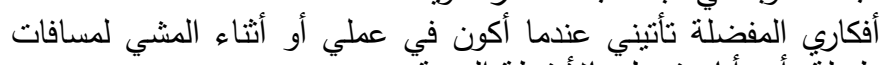
طويلة، أو وأنا مشغولَّب بالأنثطة البنانية.

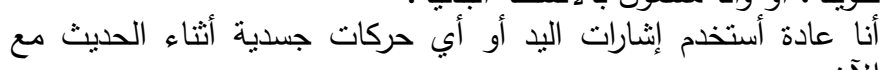
الآخرين. أرغب في النترب على مهارات جديدة أكثر من رغبتي في القراءة عنها أو

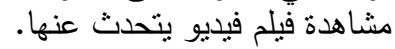


درجة)، (10,0 درجة)، (10,ץ درجة) على التزتيب.

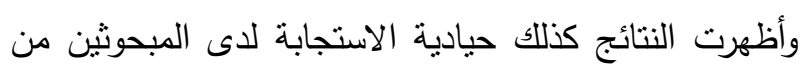

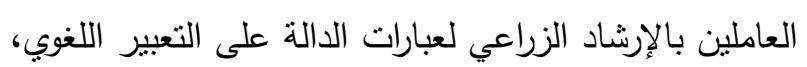

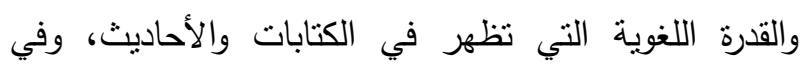

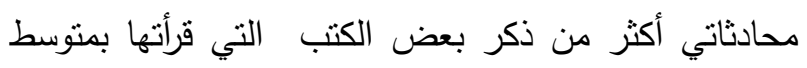

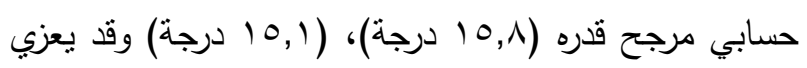

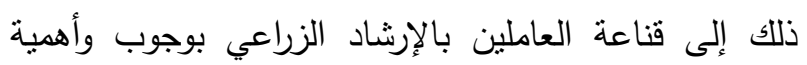

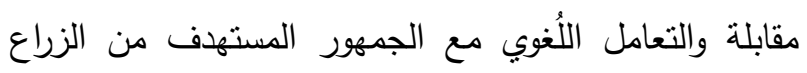
بالوادي الجديد والذي يستلزم تتمية مهارات الذكاء اللُغوي.

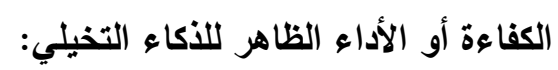
تتاول هذا النوع من الذكاء من خلال (محورين) يعبران عن درجة الذكاء التخيلي لدى المبحوثين تمثلت في: محور

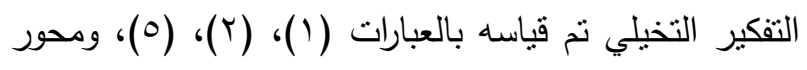

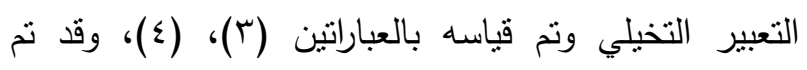

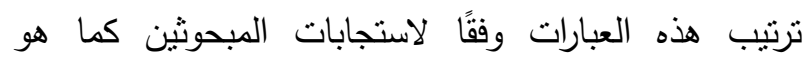

الكفاءة أو الأداء الظاهر للأكاء اللغوي: تناول هذا النوع من الذكاء من خلال (محورين) يضمان ه عبارات يعبران عن درجة الذكاء اللغوي لدى المبحوثين

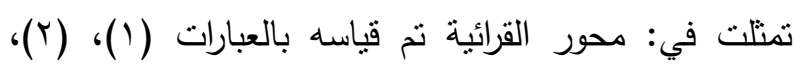

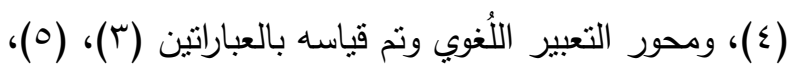

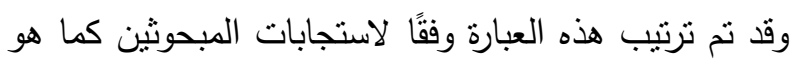

موضح بالجدول (1'). (1).

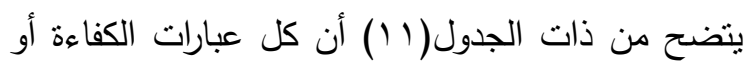

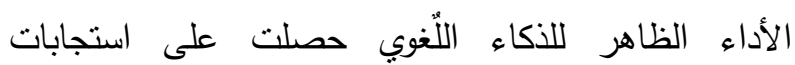
متوسطة (لحد ما) خمسة عبارات تمنل محوري القرائية، والتعبير اللغوي: حيث كانت العبارات تنور محور القرائية تقيس أهمية قراءة النشرات الإرشادية والكتب الزراعية،

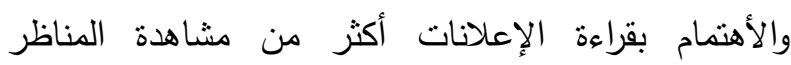
الجميلة، ومدى أهمية إكتساب المعرفة بالمواد الأدبية واللغات

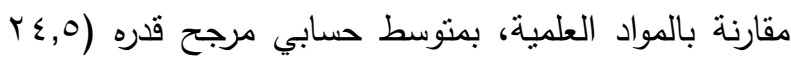

$$
\text { موضح بالجدول (r آ). }
$$

جدول 11 اـ ترتيب عبارات الأكاء اللغوي وفقًا لاستجابات المبحوثين

\begin{tabular}{|c|c|c|c|}
\hline الترتيب & الاستجابة & المتوسط الصسابي المرجح & عبارات الذكاء اللغوي \\
\hline 1 & لحد ما & $r \leqslant, 0$ & قراءة النشرات الإرشادية والكتب الزراعية مهم جدًا بالنسبة لي. \\
\hline r & 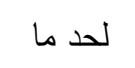 & 10,1 & مشاهدة المناظد سيارتي في طريقة سريع أهتم بقراءة الإعلانات أكثر من \\
\hline r & لحد ما لحا & 10,0 & لسؤالي حول بعض معاني الكلمات في كتاباتي أو \\
\hline$\varepsilon$ & 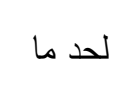 & $10, r$ & الإنجليزي والدراسات الإجيات العتماعية والتاريخ كانت أسهل عندي أيام الدراسة \\
\hline 0 & لحد ما ل لحا & 10,1 & في محادثاتي أكثر من ذكر بعض الكتب التى قرأتها. \\
\hline
\end{tabular}

جدول ץ ا. ترتيب عبارات الذكاء التخيلي وفقًا لاستجابات المبحوثين

\begin{tabular}{|c|c|c|c|}
\hline الترتيب & الاستجابة & المتوسط الحسابي & عبارات الأكاء التخيلي \\
\hline 1 & لحد ما & $r \ddot{r}, r$ & آستطيع آن أجد طربقى فى مناطق غير مألوفة. \\
\hline r & لحد ما & IV,r & يريحنى آن آفكر كيف تبدو الآشياء إذا نظر إليها من الآعلى. \\
\hline$r$ & غير موافق & 14,0 & الصور المقطعة، وألمتاهات، والألغاز . ق \\
\hline$\varepsilon$ & غير موافق & 11,1 & آرى أحلاِما تقترب من الواقع. \\
\hline 0 & غير موافق & ז & آنا عادة آرى صورًا واضحة عندما آغلق عينى. \\
\hline
\end{tabular}


الحيازة المزرعية، والخبرة الزراعية، والخبرة الإرشادية. بينما أوضحت النتائج أنه لا توجد علاقة معنوية بين درجة تميز الأداء الإرشادي للعاملين بالإرشاد الزراعي بمنطقة البحث

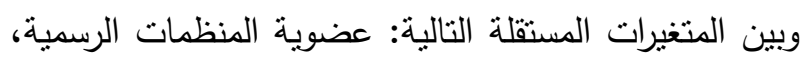
والتعرض لمصادر المعلومات الزراعية.

جدول با . علاقة درجة تميز الأداء الإششادي للمبحوثين بمنطقة البحث ومتغيراتهم المستقلة

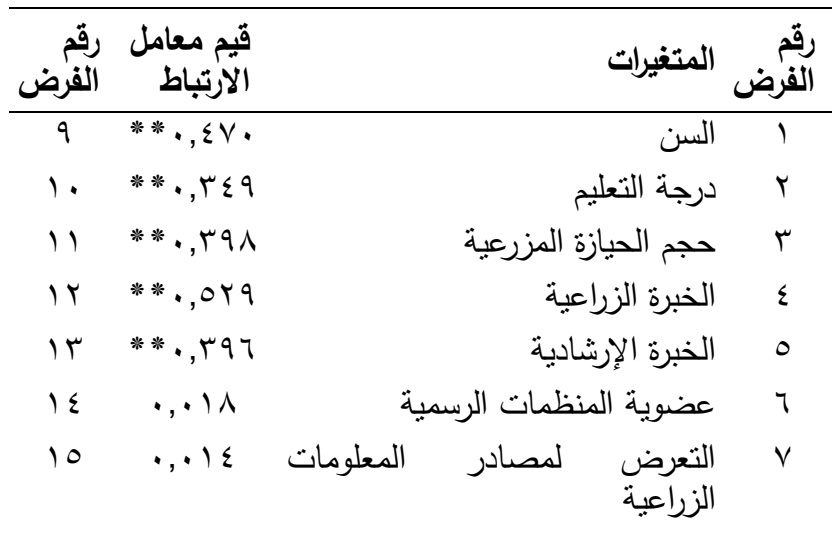

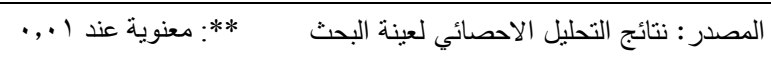

وبناءًا على تلك النتائج يمكن رفض الفروض الاحصائية

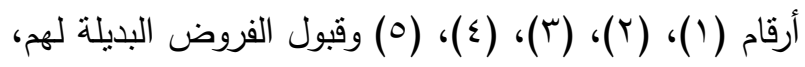

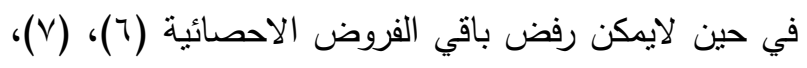
المتعلقة بتحديد العلاقة بين درجة تميز الأداء الإرشادي لإئ

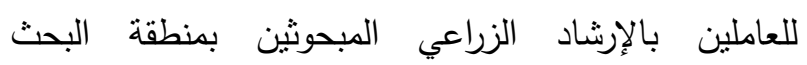
ومتغيراتهم المستقلة المدروسة".

رابعًا: التعرف على الفروق أو الاختلافات في ادراك العاملين

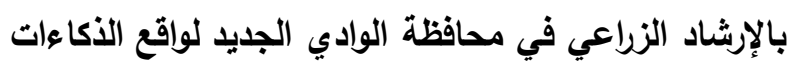
المتعددة وعلاقتها بالمتغيرات المستقلة المدروسية. للتعرف على العلاقة بين درجة الكفاءة أو الأداء الظاهري لواقع الذكاءات المتعددة للعاملين بالإششاد الزراعي المبحوثين

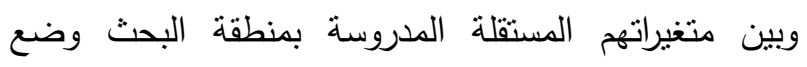
ثمانية فروض احصائية (من م- 10 1) تشترك في النص التالي: "لا توجد علاقة بين درجة الكفاءة أو الأداء الظاهري

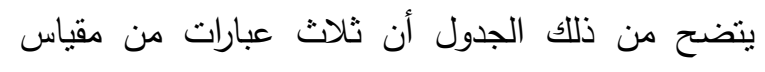

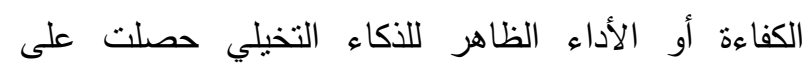
استجابات سلبية (غير موافق) : حيث كانت العبارات تدور حول محوري التفكير التخيلي والتعبير التخيلي وتمثل في عبارات تدل على صعوبة التخيل، والقدرة على إسنكمال الأجزاء الناقصة في المشاكل والمواقف الحياتية اليومية، وفقد

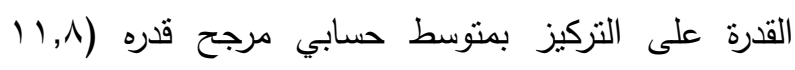
درجة)، (1,0, درجة)، (1, (1) درجة) على الترتيب. بينما وقعت عبارتين تحت استجابة حيادية (لحد ما)، تحت محور التقكير التخيلي وكانت تدور حول القدرة على أن يجد طريقه

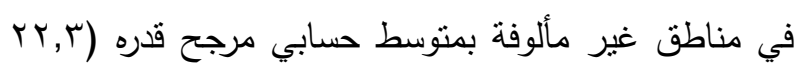

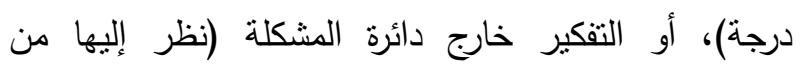
الخارج) تمثلت في عبارة يريحني أن أفكر كيف نتدو الأشياء إذا نظر إليها من الأعلى، بمتوسط حسابي مرجح قدره

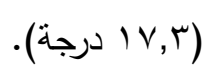

ثالثًا: العلاقة بين درجة تميز الأداء الإرشادي للمبحوثين

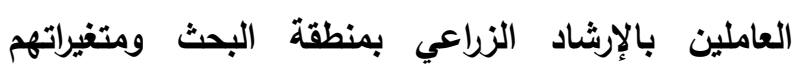
المستقلة المدروسة. للتعرف على العلاقة بين درجة تمبز الأداء الإرشادي للعاملين بالإرشاد الزراعي بمنطقة البحث ومتغيراتهم المستقلة

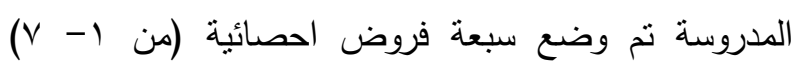
تشترك في النص التالي: "لا نوجد علاقة معنوية بين درجة تميز الأداء الإرشادي للمبحوثين من العاملين بالإرشاد

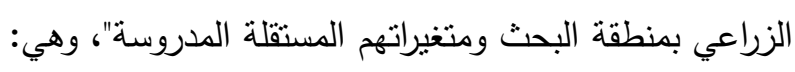
السن، ودرجة التعليم، وحجم الحيازة المزرعية، والخبرة الزراعية، والخبرة الإرشادية، وعضوية المنظمات الرسمية، ودها، والتعرض لمصادر المعلومات الزراعية.

تبين من النتائج بالجدول رقم (r) وجود علاقة إرتباطية طردية عند مستوى (1 +, •) بين درجة تميز الأداء الإرشادي

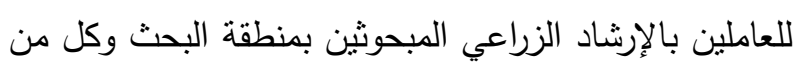
المتغيرات المستقلة التالية: السن، ودرجة التعليم، وحجم لإنيات 
لواقع الذكاءات المتعددة للعاملين بالإششاد الزراعي وبين الأداء الظاهري لواقع الذكاءات المتعددة للعاملين بالإرشاد متغيراتهم المستقلة المدروسة بالوادي الجديد"، وهي: السن، الزراعي وبين المتغيرات المستقلة التالية: السن، وحجم الحيازة ودرجة التعليم، وحجم الحيازة المزرعية، والخبرة الزراعية، المزرعية، والخبرة الزراعية، والخبرة الإرشادية، وعضوية والخبرة الإرشادية، وعضوية المنظمات الرسمية، والتعرض المنظمات الرسمية.

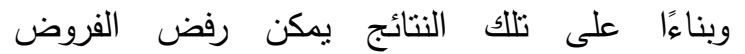
لمصادر المعلومات الزراعية، وتميز الأداء الإششادي. الاحصائية رقم (9)، (ع ()، (0) (1)، وقبول الفروض البديلة تبين من النتائج بالجدول رقم (ع ا ) وجود علاقة إرتباطية

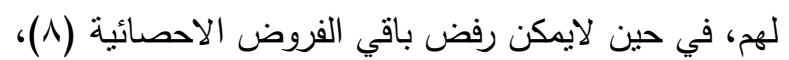
طردية عند مستوى (1.,.) بين درجة الكفاءة أو الأداء

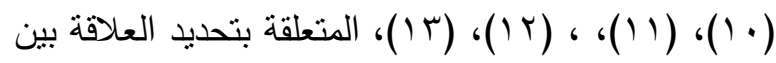
الظاهري لواقع الذكاءات المتعددة للعاملين بالإرشاد الزراعي درجة الكفاءة أو الأداء الظاهري لواقع الذكاءات المتعددة

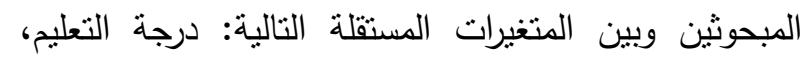

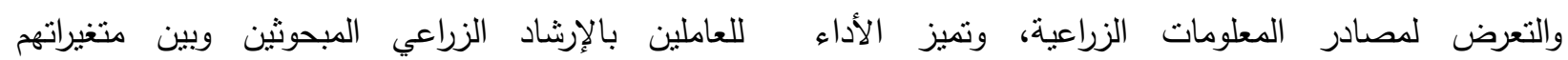
الإرشادي. بينما لا توجد علاقة معنوية بين درجة الكفاءة أو المستقلة المدروسة بمنطقة البحث.

جدول ؛ ا. ـ العلاقة الارتباطية بين درجة الكفاءة أو الأداء الظاهري لواقع الأكاءات المتعددة للعاملين بالإشاد الزراعي المبحوثين وبين متغيراتهم المستقلة المدروسة بمنطقة البحث

\begin{tabular}{|c|c|c|c|c|c|c|c|c|c|}
\hline \multicolumn{8}{|c|}{ قيم معامل الارتباط } & \multirow{2}{*}{ المتغيرات } & \multirow{2}{*}{ لفرض } \\
\hline ذاتي & بيئي & تخيلي & منطقي & حركي & لغوي & إجتماعي & إلذكاليّي & & \\
\hline$\cdot, 197$ & י & $-* *, \Gamma \wedge \varepsilon$ & $-\cdot, \cdot Y l$ & $\cdot, \cdot \leq \wedge$ & $-* *, \varepsilon \ldots$ & $* *,, \Sigma\rceil$. & $\cdot, \cdot 1 \varepsilon$ & 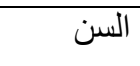 & $\Lambda$ \\
\hline$-\cdot, \cdot 11$ & $\cdot, 10 \leqslant$ & $*$, , Y 90 & **, * ש & $* *, r \circ r$ & $* *$, TVV & $\cdot, \cdot r$ & $* *$, , & درجة التعليم & 9 \\
\hline •, YY &., $1 Y 9$ & -**, r r & $-\cdot, 17 \varepsilon$ & ד7 & $\cdot, \cdot \vee 7$ & $\cdot, 1 \ldots$ & rre., & الحبزازة & 1. \\
\hline$*, Y \vee V$ & *., rqu &,$- r Y q$ &.,- 191 & • & $\cdot, 171$ &., 110 & $\cdot, \cdot \leq \wedge$ & الخبرة الزية & 11 \\
\hline$\cdot, 197$ & $\cdot, r \cdot \Lambda$ & $-\cdot, \cdot r$ & $-\cdot, \cdot r \varepsilon$ & $\cdot, 1 \cdot 1$ & $-* *,, \Sigma 9 \wedge$ & $*, Y \vee \vee T$ & ., t. & الإربرة & Ir \\
\hline.,- .09 & q & -**, , $\Sigma \curlyvee \wedge$ & מז', & $*, r \vee I$ & $* *, r \vee \leq$ & $\cdot, 1 \leq 0$ & $\cdot, \cdot 9$. & الرنظميات & r \\
\hline *, , rVT & $* *$, ror & $\cdot, Y 10$ & **, * * & $\cdot, \cdot \vee \wedge$ & $* *,, \varepsilon \cdot 1$ & $\cdot, 1 \leq \Lambda$ & $* * ., \varepsilon 11$ & المصنرض الزعرض المعاد & $1 \varepsilon$ \\
\hline$* *, \vee \vee 9 \leq$ & $* *,, \leq \varepsilon \leq$ & $\cdot, 10 \leqslant$ & سזr, & •, & -*, r r & $\cdot, r \ldots$ & $* *, r \circ V$ & الأميز & 10 \\
\hline
\end{tabular}




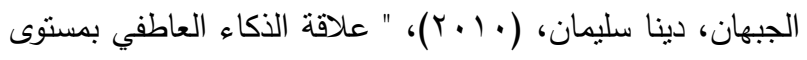

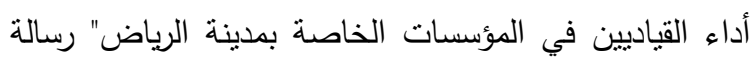
ماجستير ، الأكاديمية العربية، عمان، الأردن. الحامولي، عادل إبراهيم محمد، إسماعيل، عبد الخالق علي، السيد،

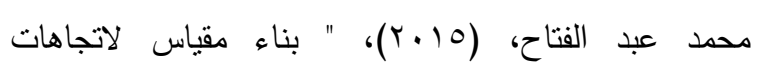
المرشدين الزراعيين والقادة الإرشاديين نحو استخدام التليفون

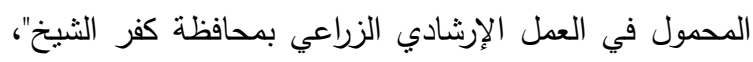

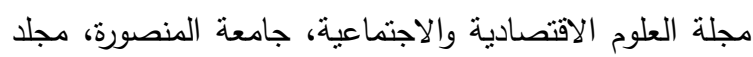

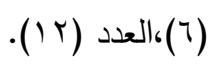
العياصرة، وليد توفيق،(11 (Y)، " التفكير واللغة " ، دار أسامة للنشر والتوزيع، عمان. الشوا، جُمانا ماهر ، (10 • ب)، " الذكاء العاطفي وعلاقته بسلوكيات المواطنة التظيمية، دراسة تطبيقية على بنك فلسطين في محافظات غزة"، رسالة ماجستير غبر منشورة، جامعة الأزهر، غزة.

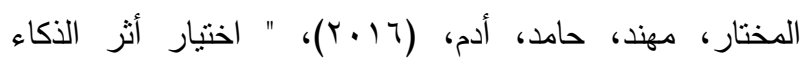
الثخصي على صناعة القرار: دراسة تطبيقية على أكاديمية

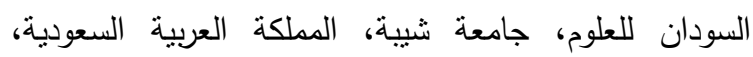

$$
\text { والإمام المهدي، السودان". }
$$

بدوي، أحمد عثمان، (Y (Y)، "دراسة تحليلية للهيكل التنظيمي

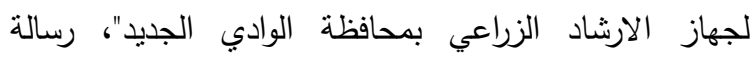
دكتوراه، كلية الزراعة، جامعة المنيا.

جنسن، إيريك، (rا +r)، " التدريس الفعال : . . . 1 طريقة عملية

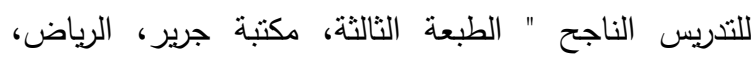

$$
\text { المملكة العربية السعودية. }
$$

حسين، محمد عبد الهادي، (11 (1)، "قياس وتقييم قدرات الذكاء

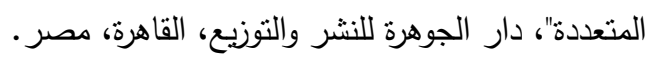
سلمان، مثال عبد اللطيف، (10 ب)، "أداء المرشدين الزراعيين لبعض المهام الإرشادية وعلاقته برضاهم عن المناخ التنظيمي-دراسة ميدانية في المنطقة الوسطى من العراق"،

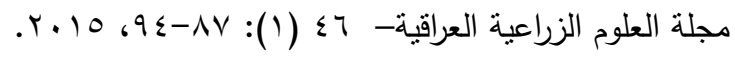

\section{التوصيات}

1-تكثيف التدريب المتخصص إرشاديًا مع التركيز على فهم

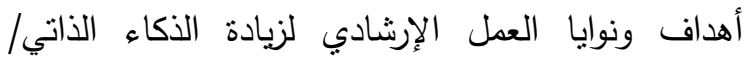
الشخصي للعاملين بالإرشاد الزراعي بمحافظة الوادي لإسي الجديد.

ץ-ضرورة الاهتمام بتتمية الذكاء المنطقي لدى العاملين بالإرشاد الزراعي بمحافظة الوادي الجديد. وكذلك تقوية

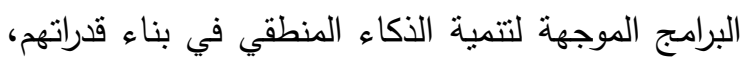
ويؤكد ذلك نفور العاملين بالإششاد الزراعي من إجراء العمليات الحسابية ذهنيًا، والبعد عن الإجهاد الذهني والميل إلى التقديرات الوهمية التي أحيانًا تبتعد عن التئن المنطق.

r-الذكاء اللغوي يأتي في الترتيب قبل الأخير بالنسبة للاككاءات وهو من الذكاءات التي بلزم أن تتوافر في لاءي المرشد الزراعي لذلك فمن الطبيعي أن يتم دعم البرامج التدريبية التي تتمي وظائف اللُغة لاى المرشدين وأهمهر: الوظيفة النفعية، والوظيفة التتظيمية، والوظيفة التفاعلية، والوظيفة الثخصية، والوظيفة الاستكثافية، والوظيفة التخيلية، وأخيرًا الوظيفة الإخبارية الإعلامية.

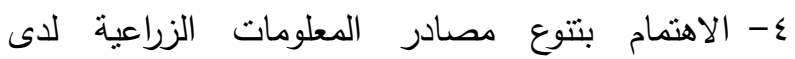
المرشدين الزراعيين لوجود علاقة ارتباطية قوية بينه وبين درجة الكفاءة أو الأداء الظاهري لواقع الذكاءات المتعددة لردئ

$$
\text { للعاملين بالإرشاد الزراعي. }
$$

\section{المراجع}

إبراهيم، نبيل رفيق محمد، (^ . . ץ)، الذكاءات المتعددة لدى طلبة

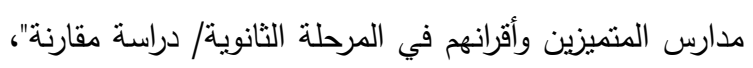
رسالة دكتوراة غير منشورة، الجامعة المستصرة، الجزائر . 
من وجهة نظر مسئولى مراكز الإرشاد الزراعى"، المجلة

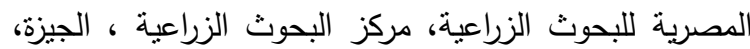

$r: \Lambda$

محافظة الوادي الجديد، النوتة المعلوماتية، (·r.r)، بيانات غير

$$
\text { منشورة. }
$$

محافظة الوادي الجديد، مديرية الزراعة، إدارة الإرشاد الزراعي،

(Y.Y.Y)، " كثوف المرشدين الزراعيين على مستوى محافظة

$$
\text { الوادي الجديد- مديرية الزراعة"، بيانات غير منشورة. }
$$

Krejcie, R, E,W, Morgan, “ Determination sample size for study Activities in Educational and Psychological measurement", vol,(30), College Station, Burham, North Carolina, USA, 1970.

Gardner, H., (1983), Frames of mind: The theory of multiple intelligence, New York, Basic Book.
شواهين، خير سليمان، (ع ا ب)، "نظريات الذكاءات المتعددة،

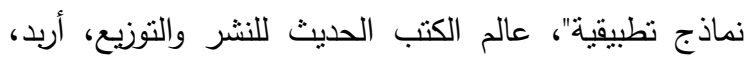

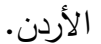

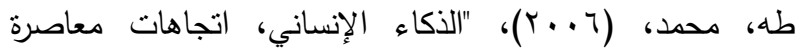

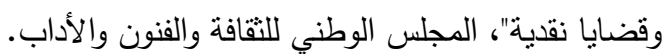

عبد الرضا، رشيد صالح، (ع ا • ب)، " دور رأس المال الفكري في

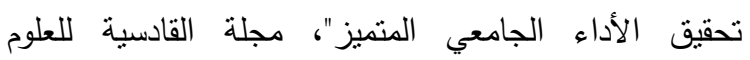

الاقتصادية، جامعة القادسية.

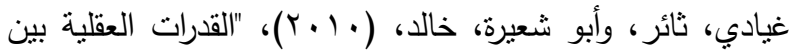

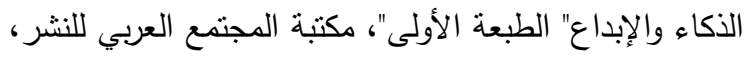

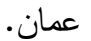

فريد، محمد أحمد وعبدالهادى، محمد عبدالجواد (r . . r)، "جودة

الخدمة الإرشادية الزراعية لمراكز الإرشاد الزراعي فى مصر - 


\title{
ABSTRACT \\ The Reality of Multiple Intelligences and The Relationship on Performance Excellence Among the Workers in Agricultural Extension in New Valley Governorate
}

\author{
Hassan Mahmoud Hassan Shafey, Ahmed Othman Badwey
}

This research aimed at identifying The Reality of Multiple Intelligences and the relationship on Performance Excellence Among the Workers in Agricultural Extension in New valley gavernorate by achieving the following objectives:1) Identify the Reality of Performance Excellence Among the Workers in Agricultural Extension in New valley distraction. 2) Identify the Reality of Multiple Intelligences Among the Workers in Agricultural Extension in New valley distraction.3) Identifying the differences or differences in the awareness of agricultural extension workers in the New Valley Governorate to the reality of Performance Excellence due to the performance excellence and personal variables of the respondents. 4) Identifying the differences or differences in the awareness of agricultural extension workers in the New Valley Governorate to the reality of multiple intelligences due to the performance excellence and personal variables of the respondents.

A simple random sample was selected from the files of Agricultural Extension specialists in New Valley Governorate. The sample was (60) Agricultural Extension specialists representing (84.0\%) from Agricultural Extension specialists. Data were collected through the personal interviews with the respondents during February to March 2021.

To analyze the data in this research statistically, it has been used Pearson correlation coefficient. In addition to the numerical and tabular presentation of repetitive and percentages, and the arithmetic mean, standard deviation, to display some of the results that have been obtained by, using the computer program Statistical Package for the Social Sciences SPSS

The most important results were:

1- It was found that about $31.7 \%$ of respondents have a high level of Performance Excellence Among the Workers in Agricultural Extension, while respondents with an average level and lower level of
Performance Excellence were $43.3 \%, 25.0 \%$ respectively.

*It turns out that social intelligence is such as precedence in the degree of efficiency or virtual performance of the reality of multiple intelligences for agricultural extension workers in the New Valley, and this was reflected in their responses to the expressions of the cognitive side and the behavioral side represented in the skills of dealing with farmers. And that the (natural) environmental intelligence is in the second order from the reality of the multiple intelligences of the respondents, then it is followed by the personal intelligence in an average way.

*While it became clear that the logical intelligence is in a late order in relation to the intelligences of the agricultural extension workers, as well as the kinetic intelligence that is supposed to be in line with the environment that governs the New Valley Governorate, followed by the linguistic intelligence that comes in the penultimate order in relation to the intelligences and then finally the imaginative intelligence where the respondents need to develop this type of intelligence.

2- Were found Positive correlation relationship at the level (0.01) between the degree of respondents' Performance Excellence Among the Workers in Agricultural Extension as a dependent variable and each of the independent variables: Age, educational degree, size of the agricultural possession, agricultural Experience, agricultural extension Experience.

3- Were found Positive correlation relationship at the level (0.01) between the degree of respondents' Multiple Intelligences Among the Workers in Agricultural Extension as a dependent variable and each of the independent variables: educational degree, source of agriculture information, Performance Excellence.

Keywords: Multiple Intelligences, Performance Excellence, New valley 